\title{
37. OLIGOCENE BENTHIC FORAMINIFERS FROM NORTH ATLANTIC SITES: BENTHIC FORAMINIFERS AS WATER-MASS INDEXES IN THE NORTH AND SOUTH ATLANTIC 1
}

\author{
Anne Boersma ${ }^{2}$
}

\begin{abstract}
Comparison of Oligocene benthic foraminiferal faunas from DSDP Sites 558, 563, 549, and 366 in the North Atlantic demonstrates, in the two deeper, less well preserved sections at Sites 558 and 563, lower diversity and lower abundance of benthic taxa, smaller sized individuals, and lower percentages of rectilinear species than in the shallower Sites 549 and 366 , both of which underlie upwellings through parts of the Oligocene.

In Paleogene deep-water sections (1500-3000 m paleodepths), an increase in the rectilinear:rotaloid ratio and the presence of miliolids correlate with improvement in sample preservation and an apparent decrease in carbonate dissolution. Solution-resistant species in this depth range are Globocassidulina subglobosa, Stilosmella abyssorum, and Cibicidoides cf. ungerianus; they become strongly dominant in the North Atlantic at abyssal depths, in moderately dissolved samples from which the coarse planktonic foraminiferal carbonate has been largely dissolved.

Taxa typical of the Indo-Pacific region, such as Laticarinina altocamerata, Cibicidoides verrucosus, and Heronallenia, appeared in deep-water sections in Zone-P21 time, concurrent with a slight drop in bottom-water temperatures. Rectuvigerina postprandia, another Indo-Pacific species, was confined to intermediate water depths of less than approximately $1200 \mathrm{~m}$. It migrated to the South Atlantic in Zone-P20 time and, along with other faunal changes, may signal the appearance of a new intermediate-water type.

Examination of faunas across the Eocene/Oligocene boundary and through the Oligocene from 12 North and South Atlantic locations has indicated that the distribution of Nuttallides umbonifera can be used to trace the pathways and depth-migration of newly-derived deep-water masses through the Atlantic. After the Eocene/Oligocene boundary event, the variations in the geographic occurrences of $N$. umbonifera from several deep-water and bottom-water depth sites parallel the stable isotopic records of bottom-water characteristics, thus reflecting the incursion of cooled bottom waters, which aged from south to north.

At one South Atlantic site (1000 m paleodepth), the brief but significant appearance of $N$. umbonifera is interpreted to reflect the influx of a new intermediate-water mass that entered the Atlantic during Zone-P20 time (about 32-33 Ma ago), coincident with the establishment of a circum-Antarctic surface circulation.

Faunas at all sites markedly changed their generic and intrageneric contents between the early and late Oligocene. The first appearances of several characteristic Neogene species through the upper Oligocene Zones P21-P22 are hypothesized to reflect the diachronous evolution of essentially "Neogene" water-mass stratification in the North and South Atlantic.
\end{abstract}

\section{INTRODUCTION}

Census of Oligocene benthic foraminiferal faunas at 12 Atlantic Ocean sites demonstrates their utility as tracers of bottom-water characteristics and circulation during the pronounced climatic shifts of the Oligocene. Coverage of North Atlantic benthic faunas in this study included two deep DSDP sites, 558 and 563, drilled near $3700 \mathrm{~m}$ in the central North Atlantic (Fig. 1), which were compared with (1) eastern North Atlantic deep-water faunas from the Bay of Biscay (DSDP Sites 549 and 550; Vema Core V27-134; (2) equatorial northeastern Atlantic deep-water faunas from DSDP Site 366 on the African margin; and (3) benthic faunas from six southern Atlantic sites representing a paleodepth range from 800 to nearly $4000 \mathrm{~m}$ (see Table 1 ).

This geographic coverage provided an overall picture of typical North Atlantic deeper-water benthic species from well-preserved calcareous sequences at a wide variety of locations and depths. The specific purposes of obtaining this coverage were (1) to identify possible deepwater index species for the North or South Atlantic by

\footnotetext{
${ }^{1}$ Bougault, H., Cande, S. C., et al., Init. Repts. DSDP, 82: Washington (U.S. Govt. Printing Office).

2 Address: Microclimates, Box 404, Rural Route 1, Stony Point, New York 10980.
}

comparison of faunas from deep-water sites in both ocean areas; (2) to determine whether such index species migrated through depth or latitude during the major climatic shifts of the Oligocene; and (3) to determine whether changing benthic distribution patterns could be employed to describe deep-water circulation in the North Atlantic during the Oligocene.

\section{METHODS}

\section{Biostratigraphy}

Subdivision of low-latitude Site 366 was based on the criteria of Hardenbol and Berggren (1978). At middle-latitude sites, however, lowlatitude criteria cannot necessarily be applied, owing to dissolution and/or the latitudinal effect on distributions of species. A composite of biostratigraphic criteria used to determine equivalency to the lowlatitude zones in shown in Table 2.

\section{Benthic Census}

A minimum of one sample per core from each site was processed on a $>63-\mu \mathrm{m}$ sieve. All benthic foraminifers in $0.5 \mathrm{~g}$ of the $>63-\mu \mathrm{m}$ fraction were picked and identified, and all data were determined from this $0.5-\mathrm{g}$ aliquot. Samples showing extreme carbonate dissolution were not included in this study.

\section{PALEOGENE GEOGRAPHIC AND/OR WATER MASS PROPERTY INDEXES}

Rey's 1954 study was one of the first to depict Paleogene geographic index species. Following the hypothesis 


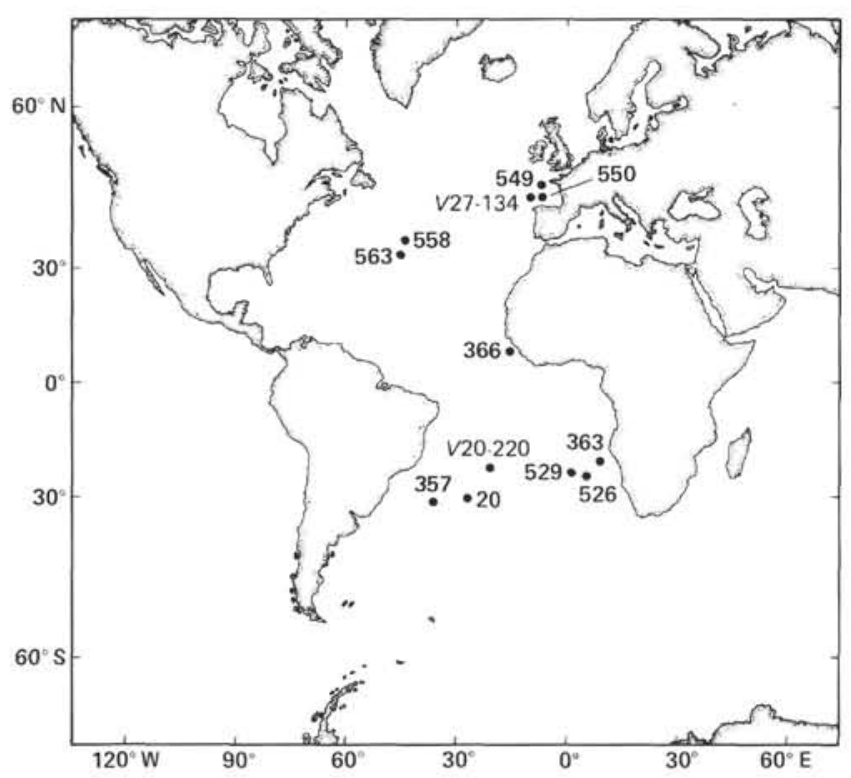

Figure 1. Location map of the 12 sites included in this study: base map redrawn from Tjalsma and Lohman (1983).

Table 1. Locations and water depths of drill sites described in this study.

\begin{tabular}{lllll}
\hline \multicolumn{1}{c}{ Site } & Latitude & Longitude & $\begin{array}{c}\text { Depth } \\
(\mathrm{m})\end{array}$ & \multicolumn{1}{c}{ Location } \\
\hline 558 & $37^{\circ} 2^{\prime} \mathrm{N}$ & $37^{\circ} 61^{\prime} \mathrm{W}$ & 3754 & Pico Fracture Zone \\
563 & $33^{\circ} 53^{\prime} \mathrm{N}$ & $43^{\circ} 4^{\prime} \mathrm{W}$ & 3786 & Mid-Atlantic Ridge \\
549 & $49^{\circ} 5^{\prime} \mathrm{N}$ & $13^{\circ} 5^{\prime} \mathrm{W}$ & 2515 & Bay of Biscay \\
$V 27-134^{\mathrm{a}}$ & $48^{\circ} 00^{\prime} \mathrm{N}$ & $12^{\circ} 6^{\prime} \mathrm{W}$ & 3350 & Bay of Biscay \\
550 & $48^{\circ} 3^{\prime} \mathrm{N}$ & $13^{\circ} 26^{\prime} \mathrm{W}$ & 4420 & Bay of Biscay \\
366 & $4^{\circ} 40^{\prime} \mathrm{N}$ & $19^{\circ} 51^{\prime} \mathrm{W}$ & 2853 & African margin \\
363 & $19^{\circ} 38^{\prime} \mathrm{S}$ & $9^{\circ} 2^{\prime} \mathrm{E}$ & 2248 & Angola margin \\
$V 20-220^{\mathrm{a}}$ & $28^{\circ} 30^{\prime} \mathrm{S}$ & $30^{\circ} 03^{\prime} \mathrm{W}$ & 4043 & Brazil Basin \\
20 & $28^{\circ} 31^{\prime} \mathrm{S}$ & $26^{\circ} 50^{\prime} \mathrm{W}$ & 4506 & Hunter Channel \\
357 & $30^{\circ} 00^{\prime} \mathrm{S}$ & $35^{\circ} 33^{\prime} \mathrm{W}$ & 2086 & Rio Grande Rise \\
529 & $28^{\circ} 55^{\prime} \mathrm{S}$ & $2^{\circ} 46^{\prime} \mathrm{E}$ & 3035 & Walvis Ridge \\
526 & $30^{\circ} 7^{\prime} \mathrm{S}$ & $3^{\circ} 8^{\prime} \mathrm{E}$ & 1054 & Walvis Ridge \\
\hline
\end{tabular}

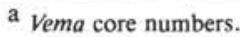

Table 2. Biostratigraphic criteria used to assign ages to middle-latitude sites.

\begin{tabular}{|c|c|}
\hline $\begin{array}{l}\text { Low-latitude } \\
\text { zone }\end{array}$ & Middle-latitude criteria indicating equivalent age \\
\hline P18-19 & $\begin{array}{c}\text { Loss of typical Eocene genera, presence of Globoquadrina } \\
\text { tapuriensis, "Turborotalia" pseudoampliapertura, and } \\
\text { Pseudohastigerina sp. without Globoquadrina sellii }\end{array}$ \\
\hline $\begin{array}{c}\text { upper } \\
\text { P18-P19 }\end{array}$ & $\begin{array}{l}\text { Presence of G. tapuriensis, "T." pseudoampliapertura, Pseu- } \\
\text { dohastigerina spp., and G. sellii }\end{array}$ \\
\hline P20 & $\begin{array}{l}\text { Loss of Pseudohastigerina spp., presence of "T." pseudoam- } \\
\text { pliapertura, and appearance of the 4-5-chambered globo- } \\
\text { rotaliid-form species such as "Turborotalia" siakensis }\end{array}$ \\
\hline P21a & $\begin{array}{l}\text { Loss of "T." pseudoampliapertura, increase in large globo- } \\
\text { quadrinids, presence of Chiloguembelina spp. }\end{array}$ \\
\hline $\mathrm{P} 21 \mathrm{~b}$ & $\begin{array}{l}\text { Loss of Chiloguembelina spp., floods of Globigerina praebul- } \\
\text { loides in fine fraction }\end{array}$ \\
\hline P22 & $\begin{array}{l}\text { Increase of large globoquadrinids, occasional presence of } \\
\text { Globigerina angulisturalis and/or Globigerina ciperoensis } \\
\text { in well-preserved faunas, presence of "Turborotalia" } \\
\text { birnagae and/or "Turborotalia" pseudokugleri and the } \\
\text { predecessor of Globoquadrina dehiscens }\end{array}$ \\
\hline
\end{tabular}

of Bettenstaedt and Wicher (1955) that there were strong similarities between Cretaceous benthic faunas throughout the world ocean, Rey compared the benthic foraminiferal faunas from several Paleogene Caribbean and Mexican localities with coeval faunas from North Africa, documenting their marked similarities. In addition, he identified several species that are dissimilar on the two sides of the Atlantic; these represented some of the first paleogeographic index species of the Paleogene.

Using similar reasoning, Berggren and Aubert (1975) distinguished Paleocene-Eocene shallower "Midway" faunas from deeper-water "Velasco" faunas, and plotted their distributions worldwide, thus further documenting the cosmopolitan distributions of many Paleogene species. "Velasco" faunas have since been charted elsewhere, for example by Schnitker (1979) in the Bay of Biscay and by Tjalsma and Lohmann (1983) at many Atlantic DSDP sites. Berggren and Aubert (1975) and Gradstein and Berggren (1981) continued to divide Atlantic Paleogene calcareous and agglutinated faunas into index assemblages named after analogous faunas from the older literature-for example, the "Barbados" fauna of Beckman (1953), the Cibicidoides mexicanus fauna first described by Nuttall (1932), and the Rhabdammina faunas known from the central European flysch basins (Brouwer, 1965).

Using the ideas of Streeter (1973), Schnitker (1974), and Bremer and Lohman (1982), among others, on the distributions of Pleistocene benthic taxa in the Atlantic, a few researchers have tried to relate distributions of Atlantic benthic foraminifers to Paleogene climatic changes and inferred water-mass characteristics. Tjalsma and Lohman (1983) used multivariate analyses to depict benthic faunal factors that could be related to changes in the oxygen-isotopic record of climate and bottom paleotemperatures. Although they reported no relationship between benthic foraminifers and the isotopically estimated paleotemperatures of the deep ocean, their data did indicate major biogeographic differentiation of benthic foraminifers in the middle Eocene at the time of the initial reduction in bottom-water temperatures (Savin, 1977; Boersma and Shackleton, 1977). Their data also suggested that a Nuttallides biofacies migrated to shallower depths during the warmest, most climatically equable phase of the Paleogene from the late Paleocene into the early Eocene. They concluded that in such regimes ocean circulation slows down, the lysocline migrates to shallower depths, and the presence of the Nuttallides biofacies reflects the migration of these more corrosive waters to shallower depths.

Schnitker (1979) demonstrated the depth migration of the bathyal benthic genus Osangularia into the abyssal regions of the Bay of Biscay during the bottom-temperature drop at Eocene/Oligocene boundary time. Miller (1982) attempted to relate changes in the Nuttallides umbonifera percentages to the carbon-isotope record at the bottom. He suggested that an acme of $N$. umbonifera in the middle Oligocene correlated with increased age and corrosiveness of bottom waters.

Boersma and Shackleton (1977) and Boersma (1977) attempted to relate increased spinosity of several Oligo- 
cene rectilinear benthic foraminifers from the Rio Grande Rise (South Atlantic) to the late Oligocene reduction in bottom-water temperatures. Boersma (1984b) demonstrated a consistent relationship between uvigerinid indexes and bottom depth in the upper bathyal zone on the Walvis Ridge. Alterations in the uvigerinid faunas, species diversity, and the rectilinear:rotaloid ratio were related to the late Oligocene decrease in bottom-water temperatures.

By analogy with the research on Pleistocene and modern benthic foraminifers, several index groups are proposed for the Paleogene. Uvigerinids are thought to characterize glacial-age, productive water masses; they are also most common in areas of high production of organic matter at the surface (Lutze, 1978) and in zones of high content of organic matter in clay along the continental margins. Several species of Rectuvigerina are limited to intermediate and shallower waters. N. umbonifera occupies corrosive, oxygen-rich, and generally cooled waters, and its abundance, along with that of other epistomellids, may be correlated with the presence of a type of Antarctic-derived bottom water. Miliolids, in part because of their high magnesium contents, are thought to be particularly susceptible to solution, and hence presumably avoid areas of colder, more corrosive bottom water. Planulina-Cibicidoides-Cibicides faunas are known to have predominated in the less productive, warmer, interglacial waters when uvigerinids became scarce, and may have alternated in abundance with uvigerinds during the Paleogene. Rectilinear benthic foraminifers, like those with large pores, are generally more susceptible to solution than rotaloid forms and therefore are not likely to occur in high percentages in corrosive bottom waters (Woodruff, 1979).

Because all these groups were present in the later $\mathrm{Pa}$ leogene of the Atlantic, their distributions and/or histories may be relatable to the climatic and temperature records of that time.

\section{BENTHIC FORAMINIFERAL FAUNAS}

\section{Site 558 (Hole 558)}

Hole 558 was drilled at $37^{\circ} 2^{\prime} \mathrm{N}, 37^{\circ} 61^{\prime} \mathrm{W}$ (Fig. 1), at a water depth of $3754 \mathrm{~m}$, near the Pico Fracture Zone of the Mid-Atlantic Ridge (Table 1). Oligocene calcareous sediments were recovered in Cores 27-18; benthic foraminifers from these cores are listed in Figure 2.

Sediments throughout the sections from Hole 558 are moderately well preserved, except in the lower two cores (27 and 26), which show evidence of strong alteration caused by contact with basement. Fossils appear dolomitized, fragmented, and cemented into lumps. Preservation deteriorates again above Core 21 (Zones P21-P22), where dissolution has removed large amounts of planktonic and benthic tests from the coarse fraction $(>250$ $\mu \mathrm{m})$ and caused erosion and fragmentation of a large number of the remaining benthic tests. Most faunas from these cores are considered to be dissolution residues and therefore nonrepresentative of true upper Oligocene benthic diversity (species richness) in this area.
In most samples, the abundance of benthic tests per $0.5 \mathrm{~g}$ of sediment, called the benthic number (BN), is considered to reflect sediment dissolution rather than initial production and/or sediment accumulation rates. An occasional sample from Zone P22, however, shows improvement in preservation, so that even the solution-susceptible species Globigerina angulisuturalis is found. In these samples, true benthic diversity is assumed.

In the best-preserved samples, the rectilinear genera, especially Stilostomella and Pleurostomella, predominate. Cibicidids and anomalinids are the most abundant rotaloid groups of the lower Oligocene; in the upper Oligocene, the cibicidids are the most abundant.

The most consistently occurring species include Oridorsalis umbonatus, Globocassidulina subglobosa, Stilostomella abyssorum, and Cibicidoides $\mathrm{cf}$. ungerianus. Since they occur in even the most dissolved samples, they may be considered dissolution-resistant forms. Uvigerina pygmaea and Pleurostomella alternans occur consistently, but only in the upper Oligocene, whereas $S$. subspinosa and Anomalinoides cf. spissiformis occur commonly only in the lower Oligocene section. The most common cibicidid is Cibicidoides havanensis.

Within genera, also, different species predominate in the lower and the upper Oligocene parts of the section. Among the uvigerinids, $U$. spinicostata in the lower Oligocene is replaced in importance by $U$. pygmaea in the upper Oligocene. The typical lower Oligocene cibicidids, Heterolepa grimsdalei and Cibicides laurisae, are replaced by Cibicidoides haitiensis and $H$. kullenbergi in the upper Oligocene. The lower Oligocene buliminid, Bulimina semicostata, has no upper Oligocene counterpart.

At least two species originally identified in New Zealand faunas by Finlay (1939) occur at Site 558. Anomalinoides orbiculus (Stache), an anomalinid with an ornamented umbilicus, was found in Section 558-25-5 (lower Oligocene). This species originated in the late Eocene in the New Zealand area. One specimen of Laticarinina altocamerata Chapman and Parr, a late Eocene to Pliocene form from New Zealand and the southwestern Pacific, occurred in Section 558-18-1 (uppermost Oligocene).

The influx of several new species in Zones P21b-P22 caused the faunas to assume a more Neogene character. These species include Pullenia quinqueloba, U. pygmaea, H. kullenbergi, Textularia sp. A, Alabamina haitiensis, and Trifarina bradyi.

\section{Site 563}

Site 563 is situated on the Mid-Atlantic Ridge (Fig. 1) at a depth of $3786 \mathrm{~m}$ (Table 1). Oligocene calcareous sediments were recovered in Cores 22 to 17 ; benthic foraminifers from these cores are listed in Figure 3. Although this section includes species from all Oligocene planktonic foraminiferal zones, the shortness of the zones suggests numerous erosional hiatuses and/or removal of large amounts of sediment by dissolution.

Preservation of the sediments at Site 563 is only moderately good to fair, and most faunas are less well preserved than their age equivalents at Site 558. Unlike sed- 


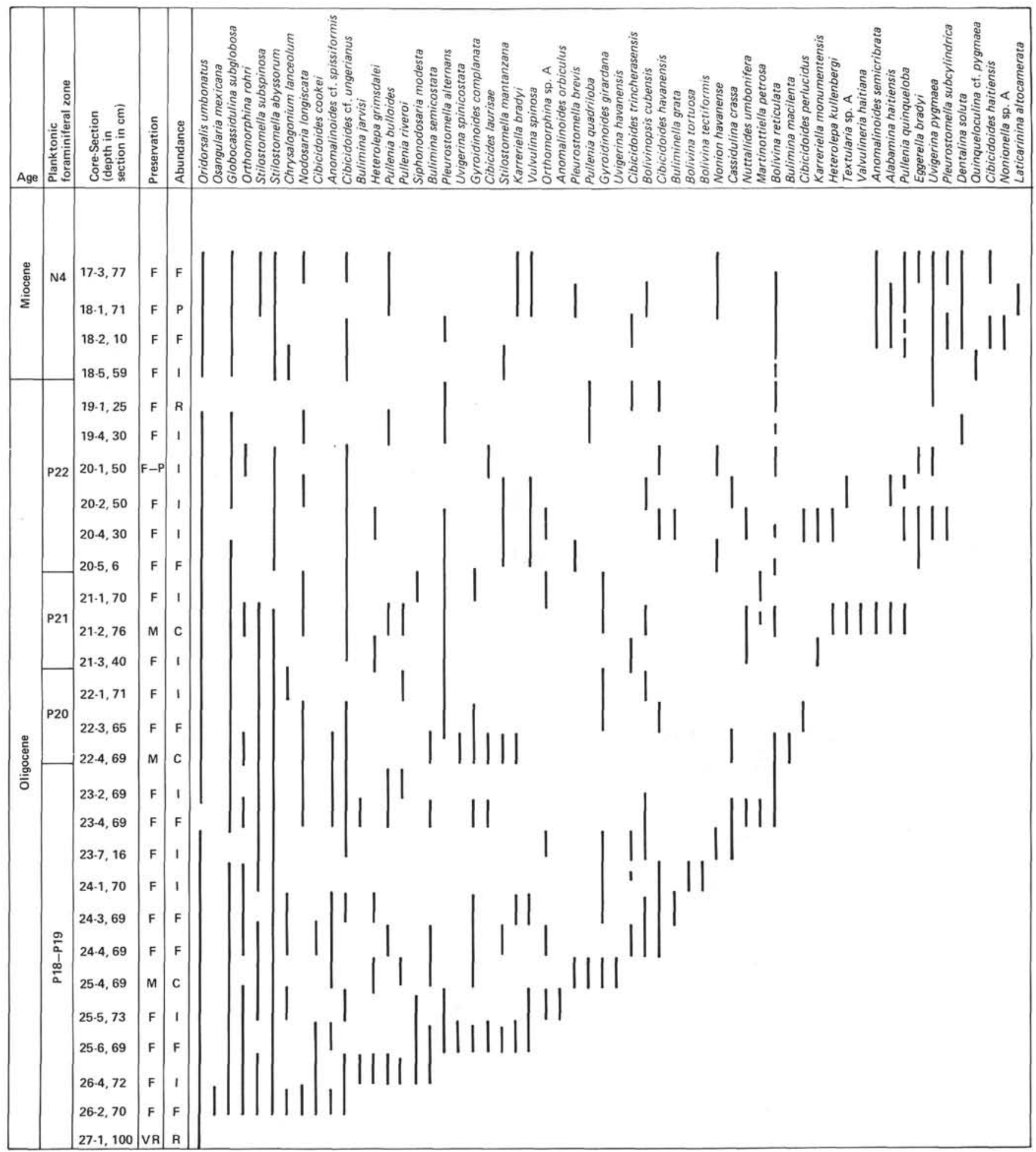

Figure 2. Stratigraphic distribution of the most common benthic foraminifers through the Oligocene at DSDP Site 558 in the central North Atlantic. Zonal assignments for Figures 2-5 and 9-10 according to the criteria of Hardenbol and Berggren (1978) and as in Table 2. G = good, M = moderate, $\mathrm{P}=$ poor; $\mathrm{A}=$ abundant, $\mathrm{C}=$ common; $\mathrm{F}=$ frequent; $\mathrm{I}=$ infrequent; $\mathrm{V}=$ very.

iments in the lower cores from Site 558, the sediments here show no evidence of contact with basement. As at Site 558, dissolution removal of large-fraction foraminifers increases markedly in upper Oligocene Zones P21bP22; benthic faunas in Cores 19 to 17 are all considered dissolution residues.
The mediocre state of preservation of most of these sediments makes it difficult to assess benthic faunal patterns. No upper Oligocene fauna is considered representative of actual benthic production or diversity in this area of the Atlantic. As at Site 558, in the best-preserved samples rectilinear genera predominate over the rotaloids, 


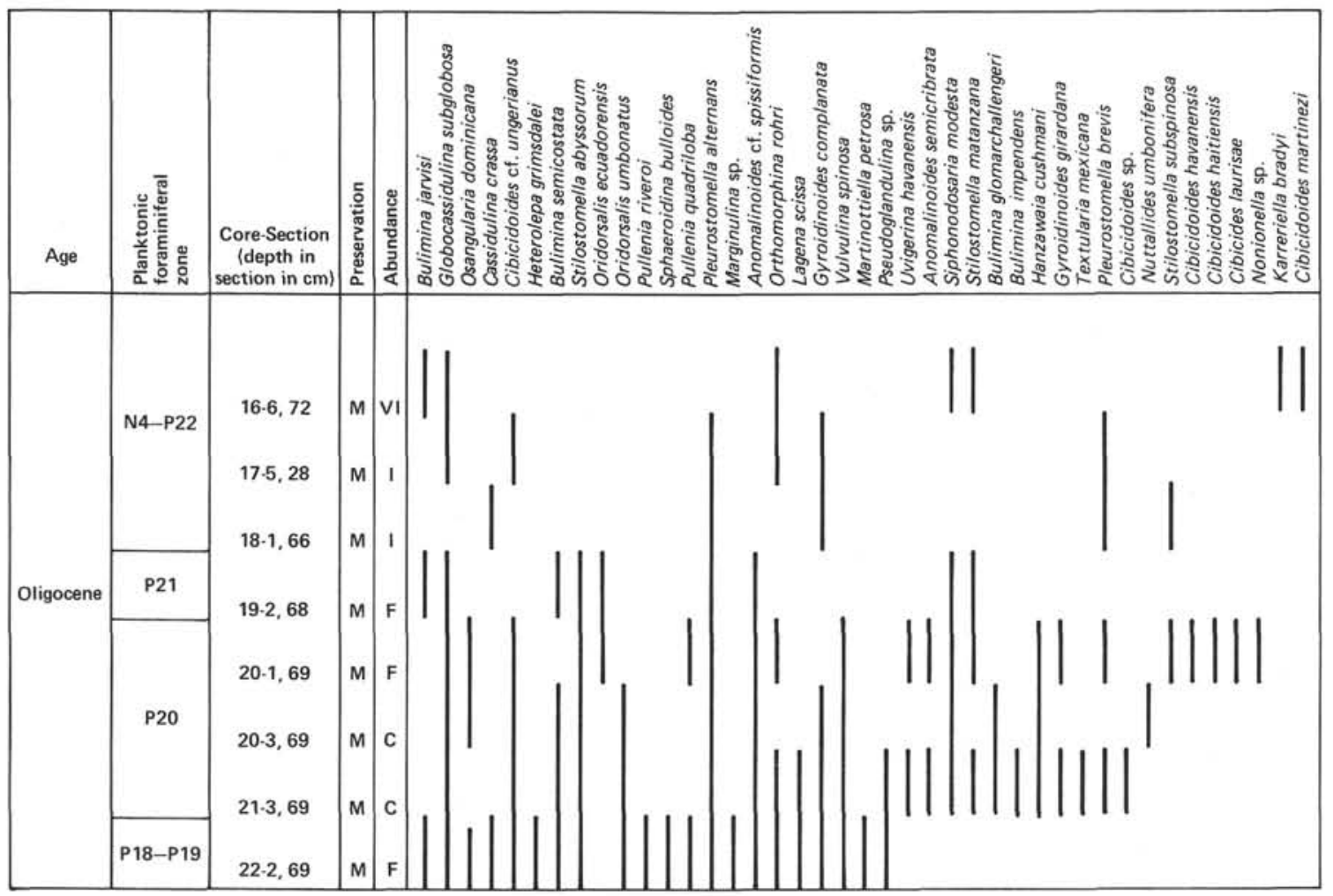

Figure 3. Stratigraphic distribution of the most common benthic foraminifers through the Oligocene at DSDP Site 563 in the central North Atlantic. Abbreviations and zonal assignments as in Figure 2.

and the cibicidids are the most common rotaloid forms. In such dissolution-depleted faunas, however, even the generic composition may not be representative of the original populations.

In the lower Oligocene, the most consistently occurring species are Globocassidulina subglobosa, Cibicidoides cf. ungerianus, and Pleurostomella alternans. The most abundant species, however, include Oridorsalis umbonatus, Hanzawaia cushmani, and Bulimina semicostata. As at Site 558, the most common buliminid is $B$. semicostata, and the most frequently encountered cibicidid is $C$. cf. ungerianus. In contrast with Site 558, the common lower Oligocene uvigerinid here is the nonspinose Uvigerina havanensis.

\section{Site 549 (Hole 549A)}

Hole 549A was drilled on DSDP Leg 80 in the Bay of Biscay (Fig. 1) at a water depth of $2515 \mathrm{~m}$ (Table 1). Oligocene calcareous-siliceous sediments were recovered in Cores 6-13; the ranges of benthic species in these cores are shown in Figure 4. The section at this site includes at least two hiatuses in the lower Oligocene and may be missing part of Zone P21 as well. In view of the siliceous contribution to the sediments, the section seems unusually short and the sediment accumulation rates too low, particularly in the upper Oligocene, where sediment accumulation increased in other oceanic areas.

Preservation at Site 549 is good in the lower Oligocene but only moderately good in the upper Oligocene. The sediments of the washed residues described here (all $>63 \mu \mathrm{m}$ ) are nearly $99 \%$ carbonate; the $1 \%$ of siliceous material consists primarily of broken radiolarians. The amount of siliceous fossils decreases in upper Oligocene Cores 9 to 6 , in which there has also been increased dissolution removal of large-fraction $(>250 \mu \mathrm{m})$ foraminifers; preservation is only moderately good throughout the upper Oligocene section.

Sixty-three species of benthic foraminifers were identified from the Oligocene section at Site 549. Maximum diversity in a well-preserved lower Oligocene sample (549A-11-4, $110 \mathrm{~cm}$ ) was 33 species. By contrast, upper Oligocene moderately well preserved samples contained only 16 to 18 species.

Individual calcareous specimens in these samples were noticeably larger than at the two previously described North Atlantic sites. Agglutinated individuals were also large, and frequently their grains were pyritized.

The most consistently occurring species were Oridorsalis umbonatus, Globosassidulina subglobosa, Hanzawaia cushmani, Cibicidoides cf. ungerianus, Stilostomella subspinosa, and Cibicides laurisae. In some samples Uvigerina spinicostata and Vulvulina spinosa also became very abundant. Species common in upper, but not lower, Oligocene faunas include Alabamina haitiensis, Cibicidoides havanensis, and a large rugose cibicidid tentatively referred to the New Zealand form $C$. verrucosus (Finlay).

The most commonly occurring group is the cibicidids; Cibicidoides haitiensis is more common in the lower Oligocene, whereas $C$. havanensis is more typical in the upper Oligocene. At the top of the section (549A-6-5, 50 $\mathrm{cm}), H$. mexicana occurs for the first time. 


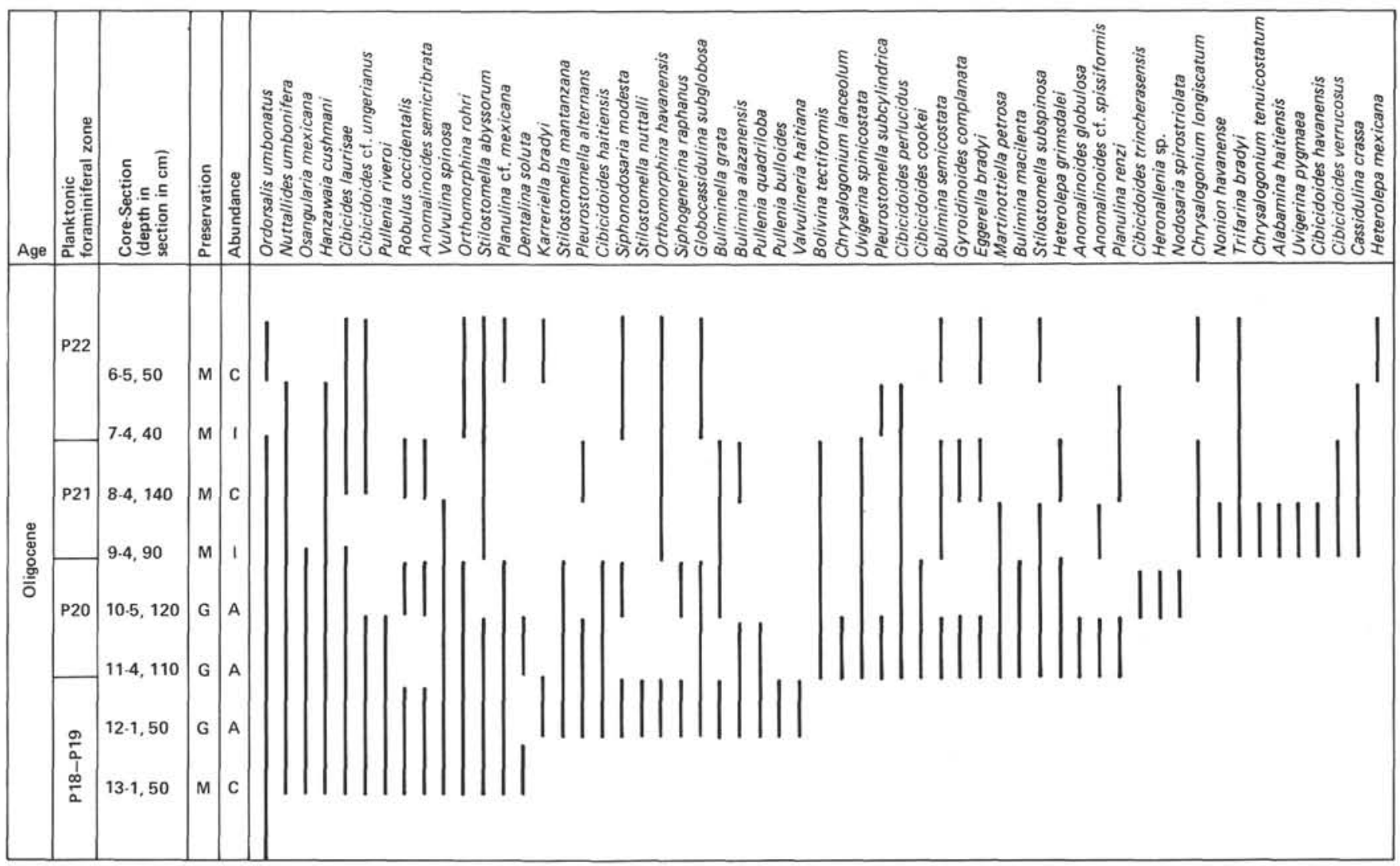

Figure 4. Stratigraphic distribution of the most common benthic foraminifers through the Oligocene at DSDP Site 549 (Hole 549A) in the Bay of Biscay. Abbreviations and zonal assignments as in Figure 2.

$U$. spinicostata, the uvigerinid typical of the lower Oligocene, becomes very abundant in the intermediate size fraction (149-250 $\mu \mathrm{m})$ in Zone P20. In this interval there is a marked increase in siliceous fossils in the washed foraminiferal fraction.

Taxa found at Site 549, but not at the deeper, more westerly Sites 558 and 563, include Robulus ex. gr. occidentalis, large nodosariids such as Nodosaria spirostriolata, and large orthomorphinids such as Orthomorphina havanensis, Gavelinella aragonensis, Anomalinoides globulosa, and Planulina renzi.

Unusually large individuals of several species appeared in Zone P20 (Section 549A-10-5), accompanied by rare specimens of the genus Heronallenia. The first occurences of this genus outside the Indo-Pacific are considered synchronous worldwide (Aubert, pers. comm., 1974).

\section{Site 366}

Site 366 , at $2853 \mathrm{~m}$ water depth on the continental slope of northwest Africa (Fig. 1, Table 1), was a locus of investigation on DSDP Leg 41. A long calcareous section with secondary amounts of siliceous fossils was recovered from Hole 366 (Cores 39 to 28) and from Hole 366A (Cores 10 to 6); faunas are listed in Figure 5. The top of Hole 366A overlaps in age (Zone P21) with the bottom of the section in Hole 366, so this long composite section appears nearly complete.

Sediments at Site 366 demonstrate variable degrees of induration, which Dean and Gardner (1978) have suggested represent Oligocene climatic cycles. Foraminifer- al faunas in the more indurated samples are moderately well preserved; in one less indurated upper Oligocene sample (366-31-1, $8 \mathrm{~cm})$, faunas are well preserved and very diverse. As as Site 549, the amount of the siliceous component in the washed residues decreases in upper Zone P21 and is minimal through the remainder of the Oligocene.

Faunas at this site closely resemble those described by Beckman (1953) from the Oligocene of Barbados. Of the 66 benthic species identified, the maximum diversity of 33 species occurs in Zone P22. As at Site 549, individual foraminifers at this site are large relative to those at Sites 558 and 563. Agglutinated foraminifers are pyritized.

The most consistently occurring species include Oridorsalis umbonatus, Globocassidulina subglobosa, Stilostomella abyssorum, Cibicidoides haitiensis, S. subspinosa, Pullenia bulloides, and Bolivina tectiformis.

Several genera are more diversified here than at any of the other sites. Eight species commonly attributed to Cibicidoides were identified. Uvigerinids, also more diverse, include Uvigerina havanensis, $U$. spinicostata, an elongate form called $U$. longa, and $U$. pygmaea. The several buliminids include Bulimina consanguinea, a taxon not found at any of the other North Atlantic sites but frequent in several deep-water sites in the South Atlantic (Boersma, 1984b).

Species found at Site 366, but not at other North Atlantic sites, are Pleurostomella ecuadorana, Laticarinina bullbrooki, Siphonina pulchra, and several miliolids. 


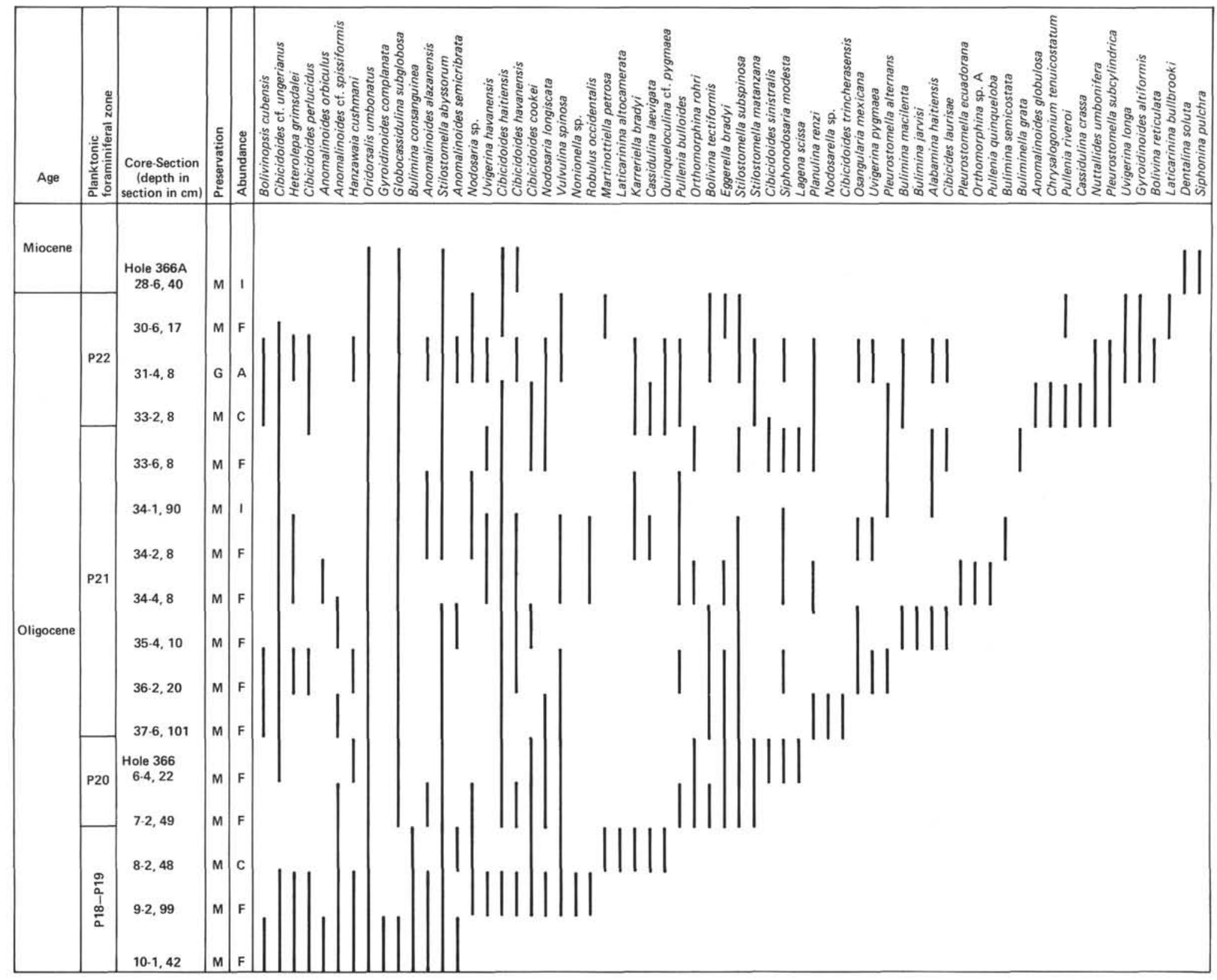


Bolivina tectiformis, Robulus spp., Planulina renzi, and Anomalinoides globulosa all occur at Sites 366 and 549, but not at the two deeper central North Atlantic sites.

Upper Oligocene faunas differ markedly from those below. Bulimina semicostata replaces $B$. consanguinea as the dominant buliminid. Other species that first occurred in the late Oligocene include Pullenia quinqueloba, Alabamina haitiensis, Nuttallides umbonifera, $U$. pygmaea, U. longa, and Pleurostomella alternans.

\section{Distributional History of Nuttallides umbonifera}

The distributional history of Nuttallides umbonifera is summarized in Figure 6 and Table 3 on the basis of its appearances and disappearances from the latest Eocene through the Oligocene at the 12 sites listed in Table 2 . The first appearance of $N$. umbonifera at these sites, not considered here as the first evolutionary appearance (which Tjalsma and Lohman [1983] record in Zone P15), occurred at the time of the intensification of bottom and near-surface temperature decreases in the Atlantic Ocean during Zone-P16 time (around $37.5 \mathrm{Ma}$ in Fig. 7). $N$. umbonifera occurred only in the western South Atlantic abyssal areas represented by Vema Core V20-220. There was, however, no eastern South Atlantic site of equivalent depth available to this study. I assume, nevertheless, that $N$. umbonifera initially adapted to and preferred the deepest, coldest areas of the South Atlantic Ocean. Tjalsma and Lohman (1983) also record N. umbonifera initially from DSDP Hole 20C, at a very deep central South Atlantic site.

Just after the Eocene/Oligocene boundary event and following the isotopic event pictured in Figure 8, N. um-

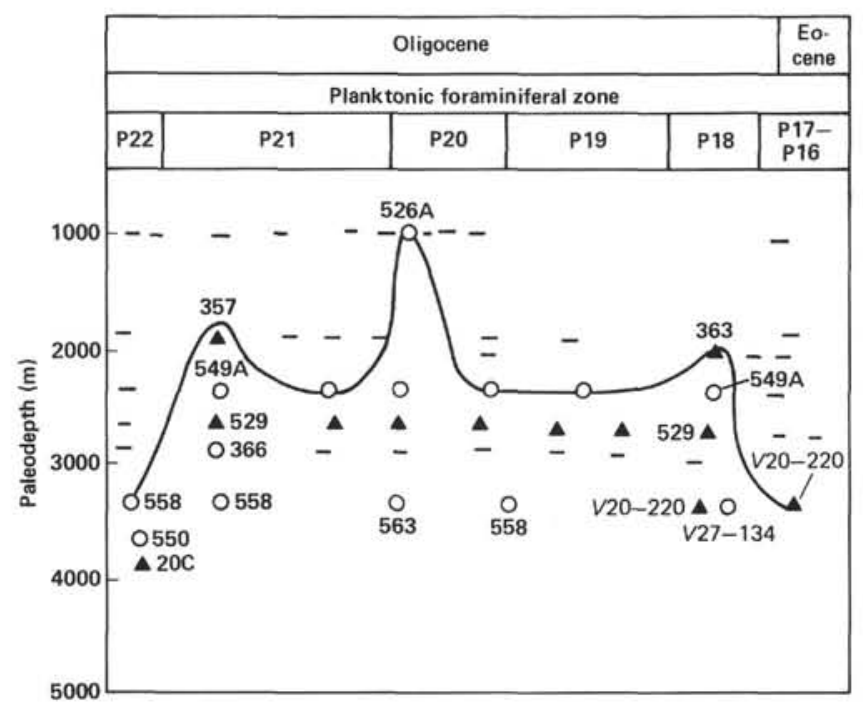

Figure 6. Schematic representation of the distribution of Nuttallides umbonifera through the latest Eocene and Oligocene in the Atlantic Ocean. Samples from the 12 sites listed in Table 1 were examined for this species; North Atlantic sites are indicated by open circles, South Atlantic sites by solid triangles. Samples examined for, but lacking, $N$. umbonifera are indicated by long dashes. Paleodepth estimates for the sites are taken from Supko, Perch-Nielsen, et al., 1977; Melguen, 1978; Moore, Rabinowitz, et al., 1984; and Boersma, $1984 \mathrm{~b}$. Sites 558,563 , and 549 are plotted slightly shallower than their actual drilling depths because their paleodepths are not presently available.
Table 3. Occurrence and abundance of Nuttallides umbonifera through the Oligocene and across the Eocene/Oligocene boundary in the North and South Atlantic.

\begin{tabular}{|c|c|c|c|c|}
\hline Hole & Level $^{\mathrm{a}}$ & $\begin{array}{c}\text { Planktonic } \\
\text { zone }\end{array}$ & $\begin{array}{l}\text { Presence of } \\
\text { N. umbonifera }\end{array}$ & $\begin{array}{l}N \text {. umbonifera } \\
\text { abundance }\end{array}$ \\
\hline$V 20-220^{\mathrm{b}}$ & 462 & P16 & $\mathrm{x}$ & 3 \\
\hline $526 \mathrm{~A}$ & $43, \mathrm{CC}$ & P16 & - & - \\
\hline 363 & $9-3,117$ & P17 & - & - \\
\hline 363 & $9-3,67$ & P17 & - & - \\
\hline 357 & $20-2,40$ & P16 & - & - \\
\hline$V 27-134$ & 260 & P16 & - & - \\
\hline $549 \mathrm{~A}$ & & P17 & - & - \\
\hline 529 & $20-2,120$ & P17 & - & - \\
\hline 529 & $20-1,120$ & P18-19 & $\mathrm{X}$ & 3 \\
\hline $549 \mathrm{~A}$ & $13-9,9$ & P18-19 & $\mathrm{x}$ & 1 \\
\hline $366 \mathrm{~A}$ & $10-2,42$ & P18-19 & - & - \\
\hline$V 27-134$ & 180 & P18-19 & $\mathrm{X}$ & 3 \\
\hline 357 & Cores 18 to 20 & P18-19 & - & - \\
\hline$V 20-220$ & 332 & P18-19 & $\mathrm{x}$ & 3 \\
\hline 558 & $23-4$ & P18-19 & $\mathrm{X}$ & 1 \\
\hline $526 \mathrm{~A}$ & Cores 41 to 37 & P20 & - & - \\
\hline $526 \mathrm{~A}$ & Core 36 & P20 & $\mathrm{x}$ & 4 \\
\hline 563 & $20-3$ & P20 & $\mathrm{X}$ & 1 \\
\hline 357 & $17-3$ & P21 & $\mathrm{X}$ & 1 \\
\hline 366 & $33-2$ & P21 & $\mathrm{X}$ & 2 \\
\hline $549 \mathrm{~A}$ & $8-4$ & P21 & $\mathrm{X}$ & 2 \\
\hline 529 & $15-3$ & P21 & $\mathrm{X}$ & 3 \\
\hline 558 & $21-3$ & P21 & $\mathrm{X}$ & 1 \\
\hline 550 & $15, \mathrm{CC}$ & P22 & $\mathrm{x}$ & 2 \\
\hline $20 \mathrm{C}$ & $2-1$ & P22 & $\mathrm{x}$ & 2 \\
\hline 357 & Cores 15 to 16 & P22 & - & - \\
\hline $549 \mathrm{~A}$ & $7-6$ & $\mathrm{P} 22$ & - & - \\
\hline 366 & $30-6$ & P22 & - & - \\
\hline 563 & $18-1$ & P22 & - & - \\
\hline 558 & $19-4$ & P22 & - & - \\
\hline 529 & $14-1$ & P22 & $\mathrm{X}$ & 2 \\
\hline
\end{tabular}

Note: Since $N$. umbonifera made up $<1 \%$ at all but Site 526 , Core 526A-36, the table reflects its relative rarity at the various sites. 1 = very, very rare; 2 = very rare; $3=$ rare; and $4=1 \%$ of the fauna picked from the $>63 \mu \mathrm{m}$ fraction. $\mathrm{X}$ indicates present; - indicates absent.

a Levels for Vema cores in $\mathrm{cm}$. Levels at DSDP sites expressed as section-core, level in $\mathrm{cm}$.

b Vema cores.

bonifera migrated from the deep South Atlantic both upward into the 2000-m depth range in the South Atlantic and northward into the North Atlantic, where it occurred through approximately $2500 \mathrm{~m}$ depth. Sample refinement at Site 529 in the South Atlantic (Boersma, 1984a) indicates that $N$. umbonifera appeared some $20 \mathrm{~cm}$ above the level of the isotopic event; but an interval of strong dissolution bracketing the isotopic event may have erased part of the record of $N$. umbonifera there. Corliss (1981) also found an offset between faunal changes and the oxygenisotopic event at the Eocene/Oligocene boundary.

Synchronous with the slight negative trend in oxygen isotopes in basal Zone P18-19 (shown on Figs. 7, 11B), $N$. umbonifera descends from the 2000-m depth range to levels below about $2500 \mathrm{~m}$. The temporary disappearance of $N$. umbonifera from Site 529 at this time is accompanied by improved carbonate preservation and a pulse of miliolids (Fig. 9). The species is still more common in the South Atlantic than in the North Atlantic.

In basal Zone P18-19, shown on Figure 6, N. umbonifera descends from the 2000-m depth range to levels below about $2400-2500 \mathrm{~m}$. The distribution of N. umbonifera, like the record of bottom temperatures, fluctuates only slightly through Zones P18-19 and into basal Zone P20. It appears, but is rare, during one interval in 


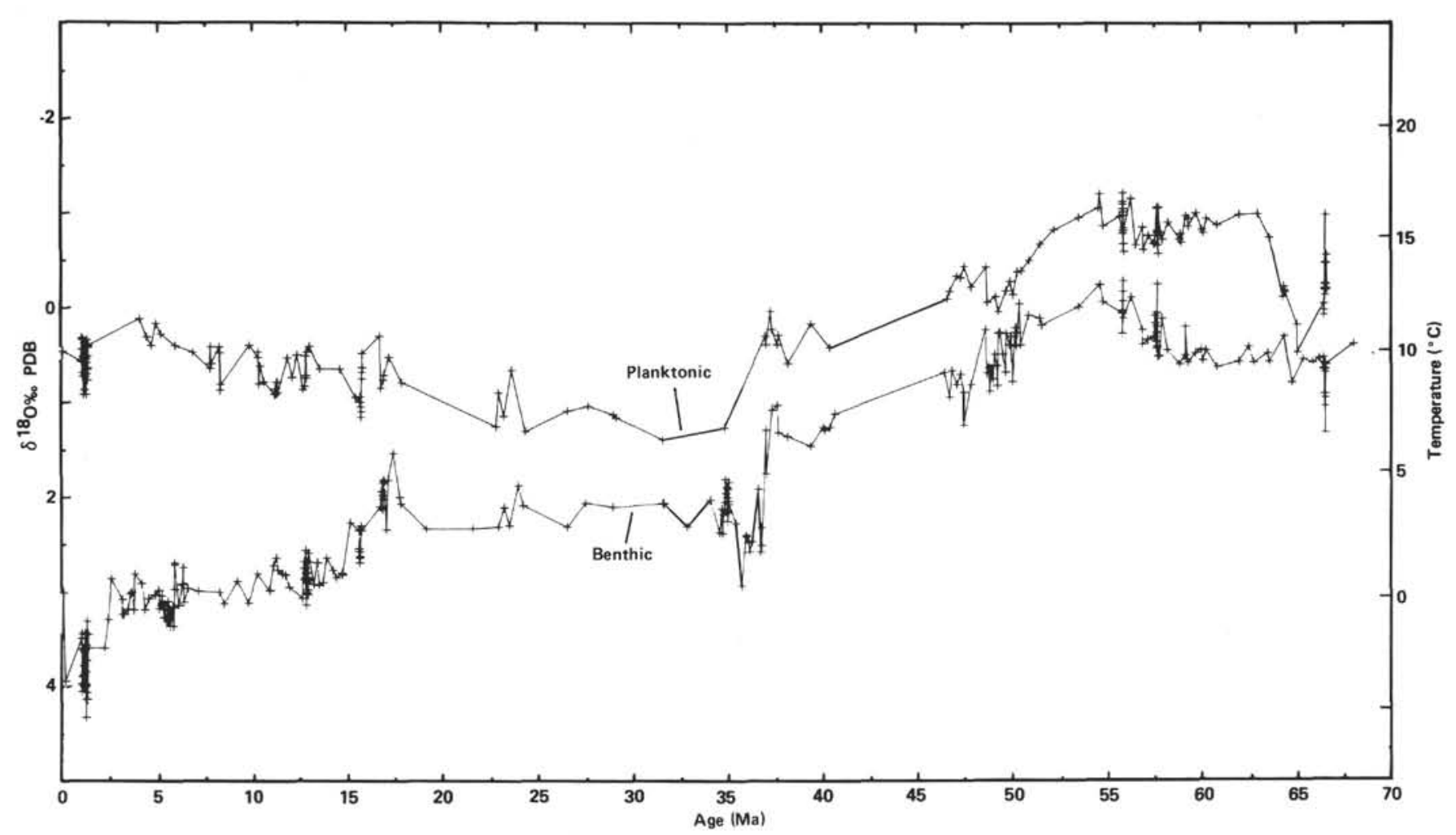

Figure 7. Oxygen isotope record in benthic and planktonic foraminifers, compiled from data for Sites 525, 526, and 529 on the Walvis Ridge (from Shackleton et al., 1984). Data are plotted on the time scale of Ness et al. (1980).

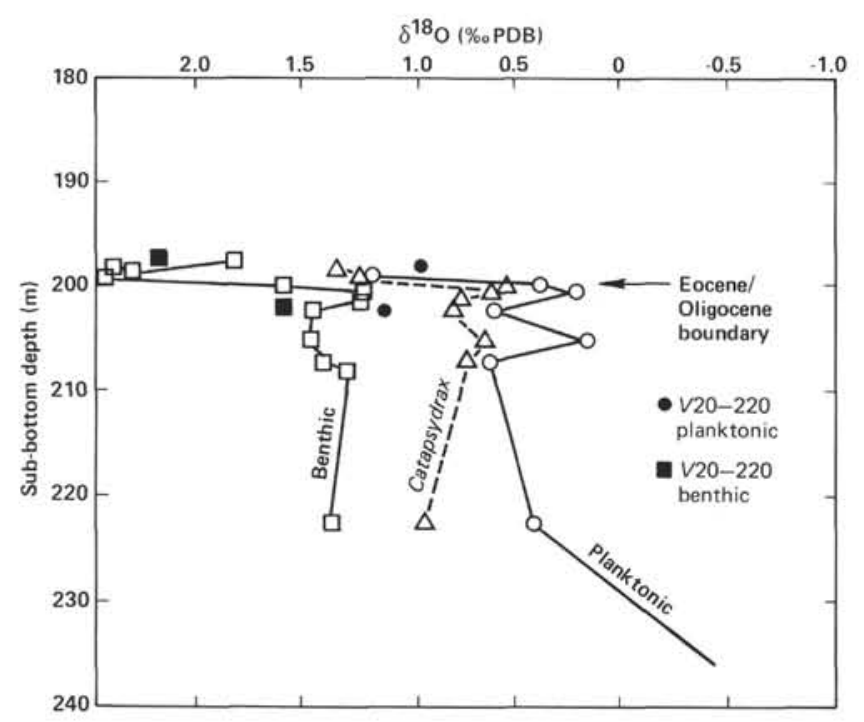

Figure 8. Oxygen-isotopic measurements across the Eocene/Oligocene boundary at DSDP Site 529 on the Walvis Ridge. The most negative value among the planktonic taxa measured was used to construct the planktonic curve. The most positive planktonic values were consistently registered by Catapsydrax spp. Benthic curves are composed of Uvigerina or Bulimina values and those for Cibicidoides spp. (from Shackleton et al., 1984).

Zone P18-19 at Site 558 (Fig. 2); the exact timing of this event is unclear, however, owing to uncertainties in the biostratigraphy. The species remains more common (though rare), and occurs more consistently, in the South Atlantic.
At most sites, N. umbonifera occurs with greater consistency beginning in Zone P20, although it is still very rare. For example, only two specimens were found in 0.5 $\mathrm{g}$ of sediment from Site 563. During Zone-P20 time it extended its depth range from near $3700 \mathrm{~m}$ to as shallow as $1000 \mathrm{~m}$ in the southeastern South Atlantic, and occupied most intermediate depths from 2000 to near $3700 \mathrm{~m}$ in both the North and the South Atlantic.

In one anomalous, brief instance, $N$. umbonifera ascended to nearly $900 \mathrm{~m}$ (Boersma, 1984b) at Site 526 on the Walvis Ridge (Fig. 10) during Zone-P20 time (about 32-33 Ma on Fig. 7). It constitutes up to $1 \%$ of the fau$\mathrm{na}$, and is thus more abundant than at any other locality included in this study. Tjalsma (1983) does not, however, report finding this species in coeval Oligocene samples from Site 516, located at equivalent paleodepths on the Rio Grande Rise in the southwestern South Atlantic. Other faunal changes at this time at Site 526 (Figs. 10, $11 \mathrm{~A}$, Sample 526-37-3, $70 \mathrm{~cm}$ ) include an increase in the ratio of rotaloid to rectilinear species, caused by a marked increase in large, fragmented robulinids; an increase in the benthic number from 249 to over 360 individuals; an increase in uvigerinids from more than $1 \%$ to over $8 \%$ of the picked fauna; a marked increase in pleurostomellids, in spinosity of buliminids, and in the ornamentation of several forms; and the first appearance of an Indo-Pacific morphotype, here called Cibicidoides semiteres. The overlying sample $(526-37-2,70 \mathrm{~cm})$ contains the first incursion of several other Indo-Pacific morphotypes, including Rectuvigerina postprandia, a form characteristic of intermediate-depth ocean sites worldwide. 


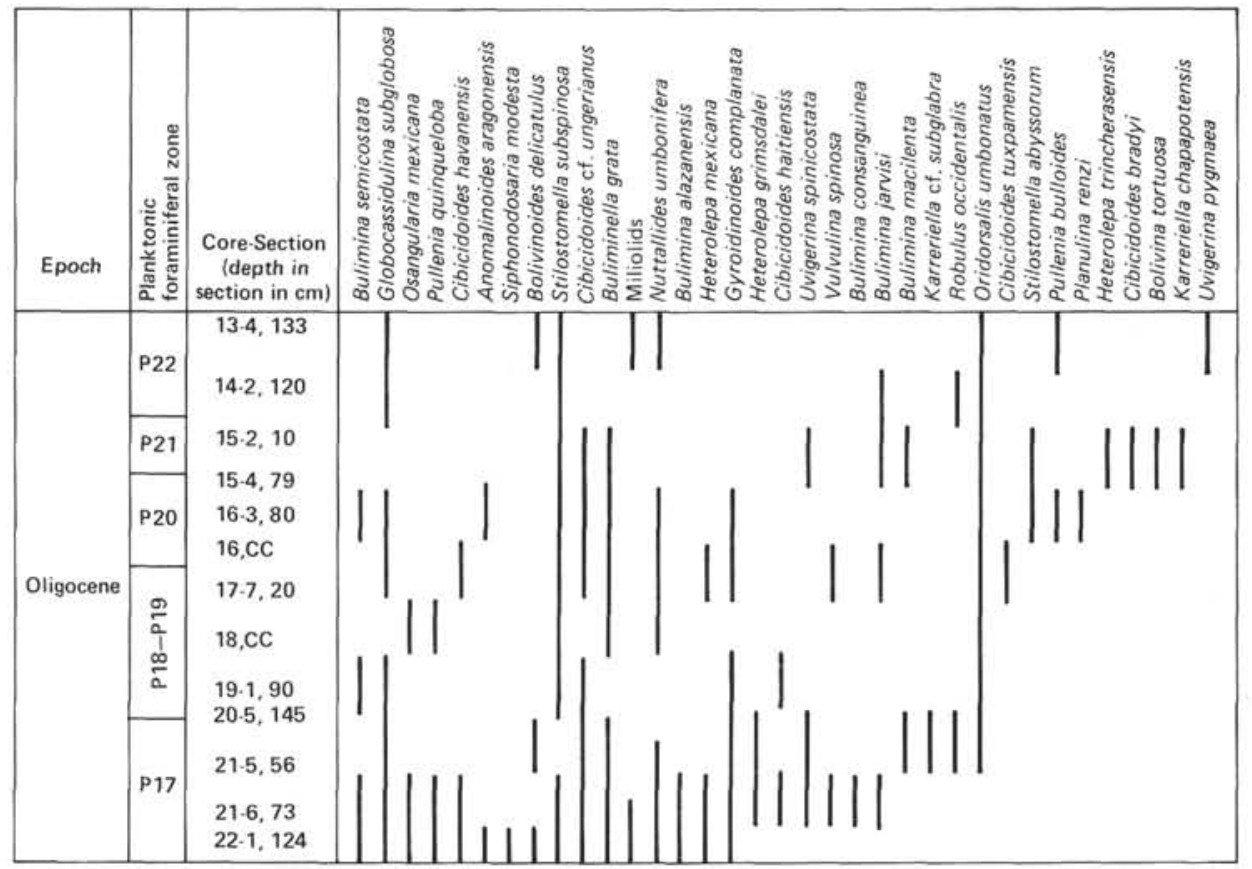

Figure 9. Stratigraphic distribution of the most common benthic foraminifers through the Oligocene at DSDP Site 529 on the Walvis Ridge.

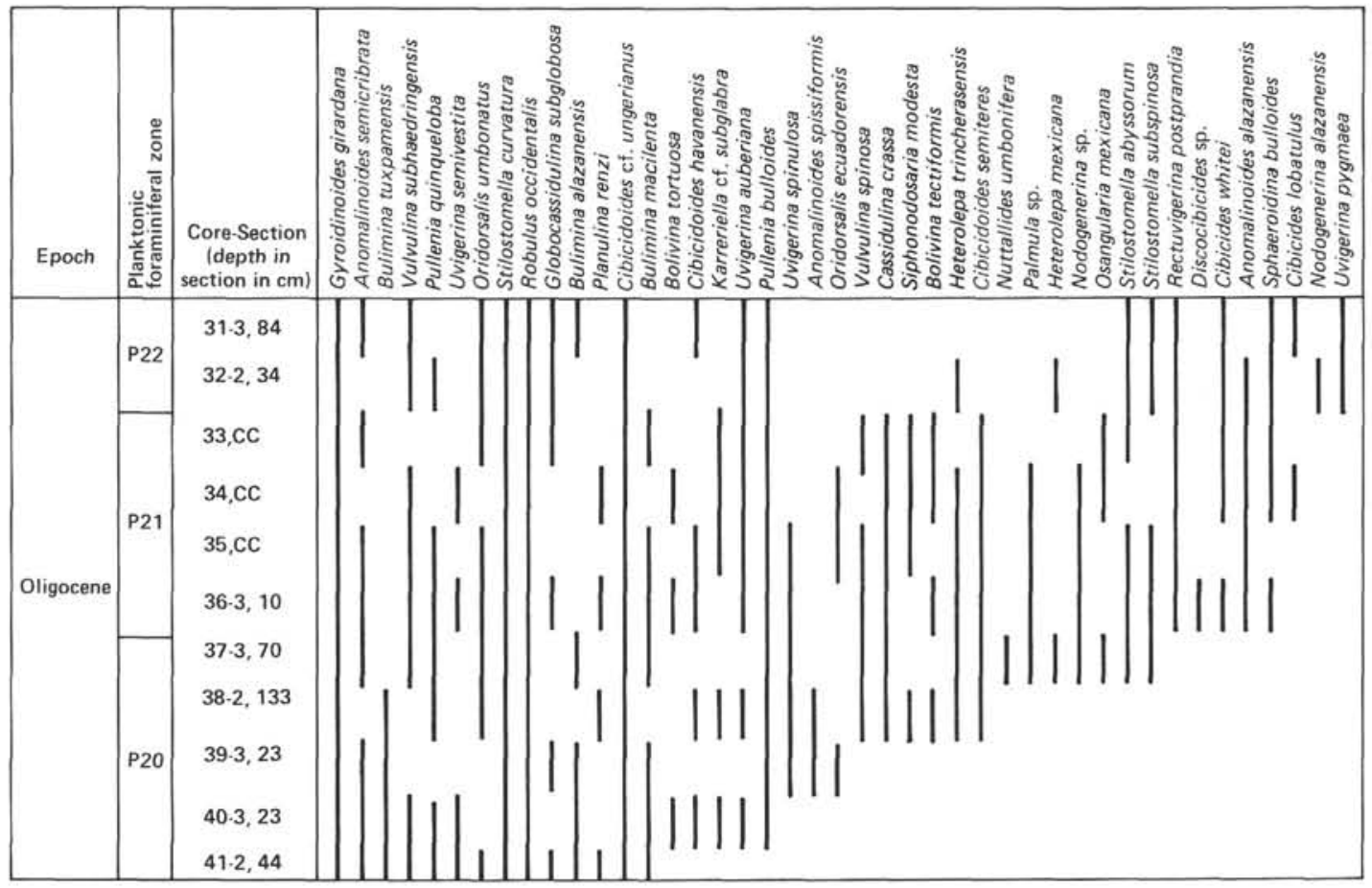

Figure 10. Stratigraphic distribution of the most common benthic foraminifers through the Oligocene at DSDP Site 526 (Hole 526A) on the Walvis Ridge.

Although sampling density is inadequate, the migration of the Indo-Pacific morphotypes, the indications of deteriorating carbonate preservation, and the increased abundance of uvigerinids all suggest the appearance of a different intermediate water impinging on the bottom at Site 526.
During Zone-P21b time, paralleling a slight positive trend in the bottom oxygen-isotope record (Fig. 7, about $26 \mathrm{Ma}$ ) which has been recorded also at DSDP Sites 357, 366, 526, and 529 (Boersma and Shackleton, 1977, 1978; Shackleton et al., 1984), N. umbonifera again ascended into the 2000-m depth range, just as it did after the Eo- 
cene/Oligocene boundary event. It spread, however, into a larger range of habitats, including Site 357 on the Rio Grande Rise and Site 366 on the North African margin, under a limited equatorial upwelling system. Again, it is more abundant in the South Atlantic than in the North Atlantic.

In conjunction with the negative trend in surface temperatures signaling the beginning of the late Oligoceneearly Miocene warming, shown in Figure 7 at about 24$25 \mathrm{Ma}, N$. umbonifera disappeared from all but the deepest basins of the North and South Atlantic, where it occurred in nearly equal abundances.

To summarize: $N$. umbonifera appeared first in the late Eocene in the South Atlantic, where it resided only in abyssal areas. Immediately after the proposed Eocene/ Oligocene boundary event and the increased carbonate dissolution at deep sites, $N$. umbonifera spread through the North and South Atlantic from abyssal depths to near $2500 \mathrm{~m}$. It was more abundant and occurred more consistently in the South Atlantic, suggesting that it was occupying conditions closer to its preferred water type. $N$. umbonifera ascended into the $2000-\mathrm{m}$ range both after the Eocene/Oligocene boundary event, during ZoneP20 time, (it occurs most consistently in Atlantic samples of Zone P20), and in Zone-P21b time, when (on the evidence of the oxygen-isotope record) cooling of bottom waters took place. This species occupied only abyssal areas in Zone-P16 time, during the gradual temperature drop preceding the Eocene/Oligocene boundary event, and again in Zone-P22 time, during the beginning phases of the late Oligocene to early Miocene warming. In this latter period, N. umbonifera occurred in nearly equal numbers at the North and South Atlantic sites and spread into areas of equatorial upwelling for the first time.

\section{BENTHIC FORAMINIFERS AS POSSIBLE TRACERS OF BOTTOM-WATER MASS PROPERTIES}

From studies of Quaternary benthic foraminifers, correlations have been suggested between the frequencies of benthic foraminiferal species and various properties of bottom-water masses. Properties of bottom or surface waters, which are reflected in the character of the sediment, are most likely to affect benthic foraminifers. It is thus feasible to seek similar relationships among Paleogene benthic foraminifers, particularly because several species already studied from the Pleistocene first occurred in the later Paleogene. Therefore, the data base of this study was expanded to include all Oligocene cores from the 12 sites listed in Table 1 , in order to track faunal changes from both the South Atlantic and the North Atlantic, and to include the Eocene/Oligocene boundary as well. Benthic foraminiferal ranges from two additional sites, 529 and 526 on the Walvis Ridge, are shown in Figures 9 and 10.

In Quaternary studies, several forms have been related to carbonate saturation levels in bottom waters. Miliolids and Nuttalides umbonifera behave inversely with respect to carbonate saturation (Bremer and Lohman, 1982), whereas rectilinear species in general reflect less carbon- ate dissolution in ancient sediments (Woodruff, 1979). In the Paleogene of Sites 558 and 563, rectilinear benthic forms increase relative to rotaloid forms in the better-preserved samples. At Site 529, miliolids first appear in the better-preserved samples just above the dissolution interval marking the Eocene/Oligocene boundary. $N$. umbonifera first appears during this same dissolution interval. It is therefore possible that these forms may reflect the state of carbonate preservation in the Paleogene, as they appear to do in the Quaternary.

In other studies of Quaternary benthic foraminifers, N. umbonifera is considered an index of Antarctic Bottom Water (AABW) (Schnitker, 1974), a "new" cooled bottom-water type deriving from the Antarctic. Bremer and Lohman (1982) suggest, however, that $N$. umbonifera may be related primarily to carbonate saturation levels in waters such as $\mathrm{AABW}$ and may characterize other bottom waters similarly corrosive to carbonates. By analogy, N. umbonifera may be useful as a tracer for Antarctic-derived "new" and corrosive water masses in the Paleogene.

Evidence at the Eocene/Oligocene boundary for the initiation of a cooled, "new" water mass deriving from the Antarctic region includes (1) the concurrent increase in sediment erosion in the North Atlantic (Tucholke and Vogt, 1979); (2) increased clay entrainment in a new bottom-water current through the Argentine Basin (Supko, Perch-Nielsen, et al., 1977); (3) increased dissolution of carbonate in deep South Atlantic basins and its replacement by siliceous sediments (McCoy and Zimmerman, 1977); (4) a discrete dissolution interval across the Eocene/Oligocene boundary at deep South Atlantic sites such as Site 529 on the Walvis Ridge (Boersma, 1984b); and (5) a strong positive peak in oxygen isotopes at the bottom (Figure 8), which is now considered to represent both a decrease in bottom-water temperatures (Shackleton and Kennett, 1975; Keigwin, 1980; Vernaud Grazzini, et al., 1979) and a compositional effect resulting from the increased volume of Antarctic glacial mass (Mathews and Poore, 1980; Shackleton et al., 1984).

This evidence suggests the origination of a "new" and erosive, cooled bottom water deriving from the south, presumably from the Antarctic region, correlative with the glacial episode at the Eocene/Oligocene boundary. The idea that these cooled, Antarctic-derived waters would penetrate into the abyssal North Atlantic is corroborated by recent evidence on Atlantic equatorial fracture zones, which indicates that passage was possible through deep channels as early as the Eocene in both the Romanche and Vema fracture zones (Bonatti et al., 1977).

Support for a southern origin of this bottom water comes also from carbon-isotopic evidence. Carbon-isotopic patterns in the Recent Pacific Ocean (Kroopnick, 1974) indicate that benthic foraminiferal ${ }^{13} \mathrm{C}$ should be depleted in "older" water which has also become increasingly depleted in oxygen along its course (Broecker, 1974). Boersma and Shackleton (1978) demonstrated south-to-north depletion in benthic foraminifers throughout the South Atlantic during the time corresponding to Oligocene Zones P18-P19. Although there are isotopic disequilibrium effects and inter-ocean and intra-ocean 


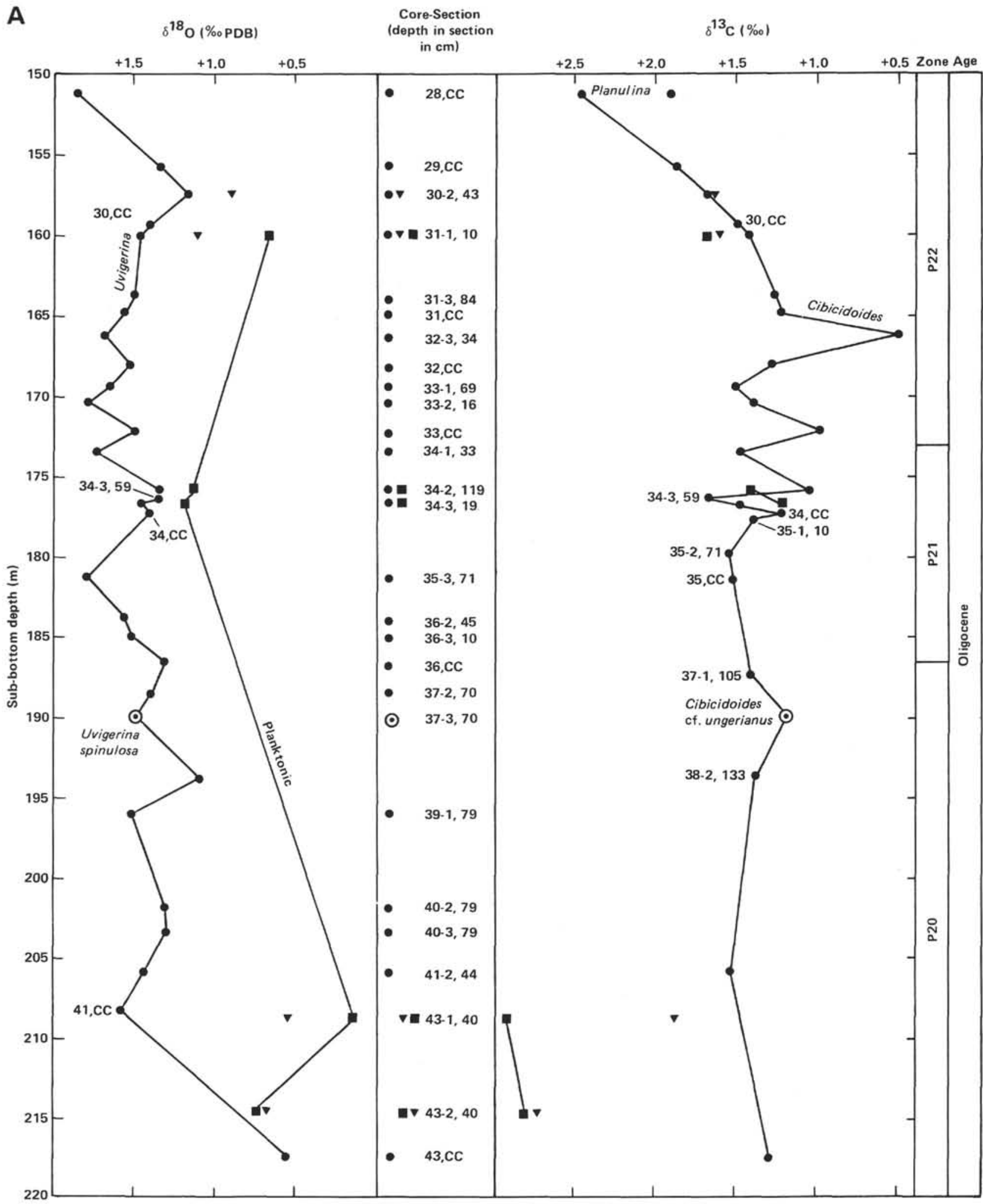

Figure 11. Oxygen and carbon isotope records through the Oligocene at (A) DSDP Site 526, Hole 526A (from Shackleton et al., 1984) and (B) Site 529. Planktonic records are constructed from the most negative planktonic taxa of those measured. Both Uvigerina and Cibicidoides curves could be constructed for this site. 
B
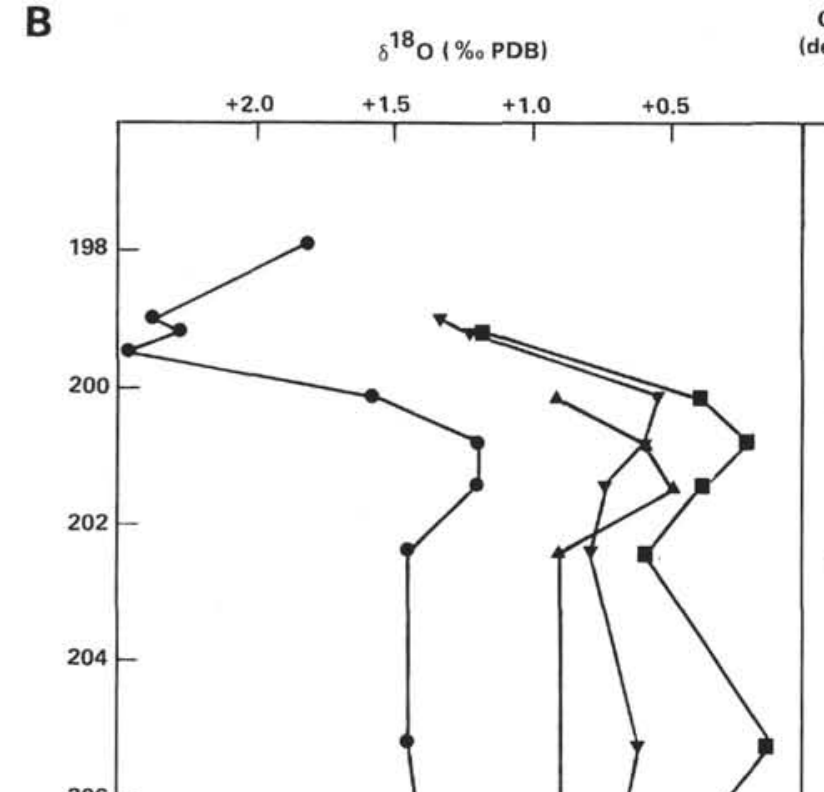

E्
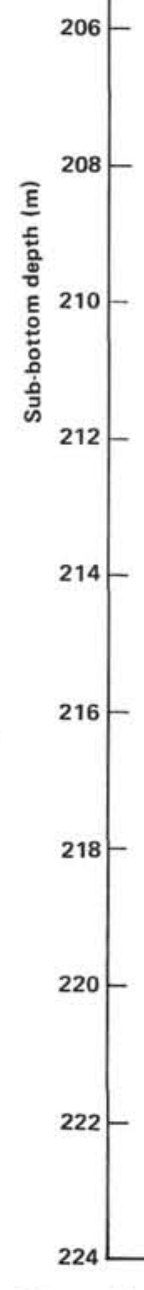

Figure 11. (Continued).

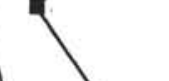

$204-$

206

-

14
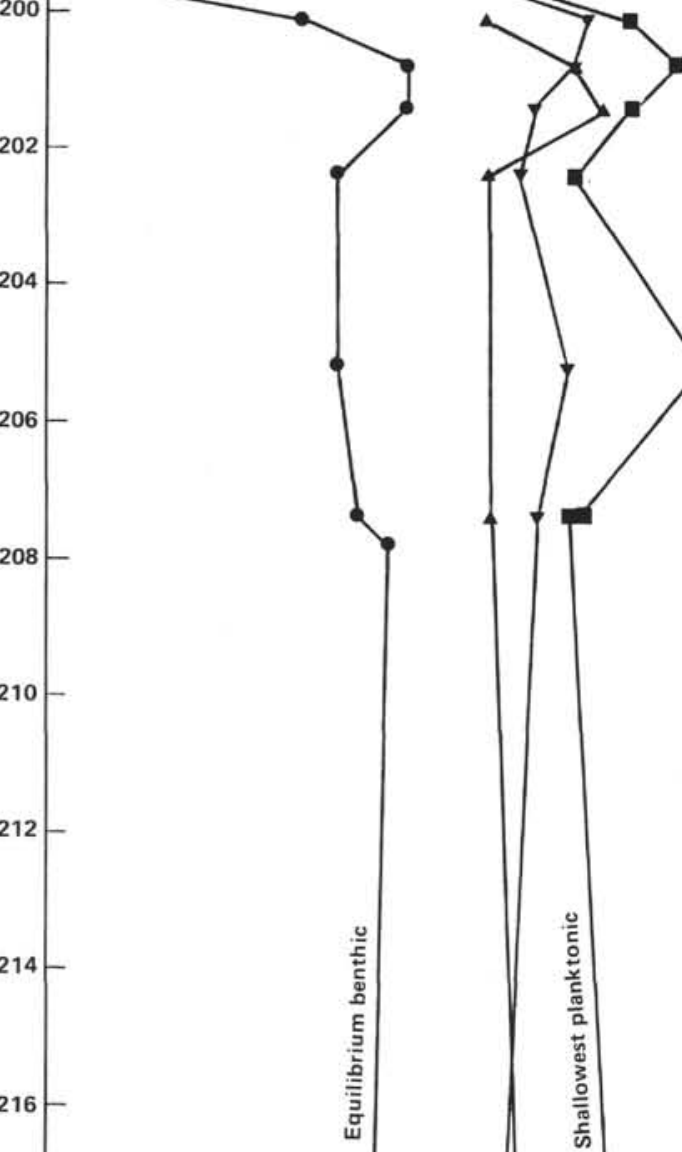

$\uparrow$
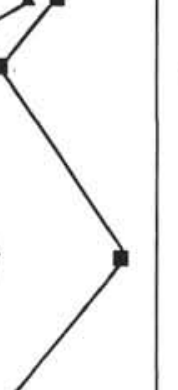

Core-Section

depth in section $\quad \delta^{13} \mathrm{C}(\% \circ)$

in $\mathrm{cm}$ )

$\begin{array}{lll}+2.5 & +2.0 & +1.5\end{array}$

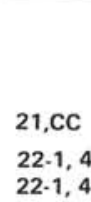

22-1, 49

22-1, 69

$22 \cdot 1,99$

22-2, 12

22-2, 77

22-2, 136

22-2, 107

$22-5,69$

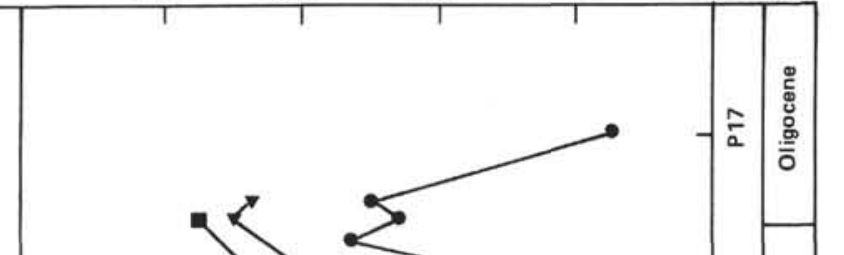

22.6, 134

$22, \mathrm{CC}$
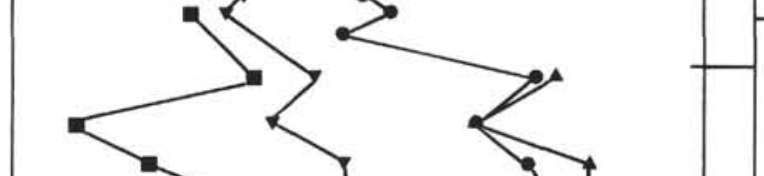

4

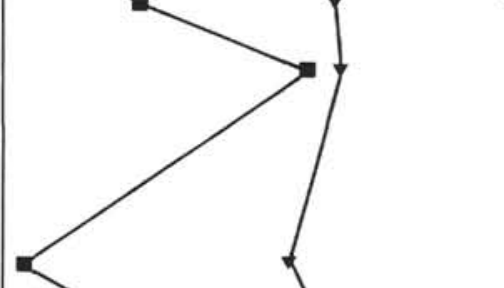

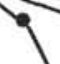

$\frac{0}{2}$

$29.4,49$
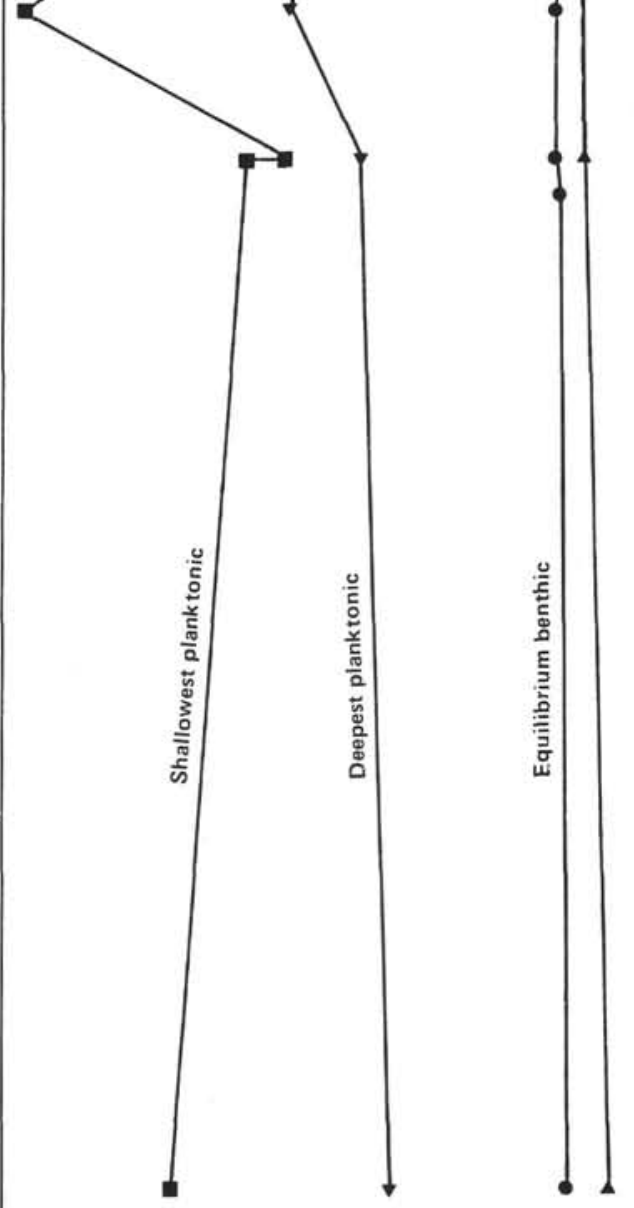

$\frac{2}{a}$ 
complexities in ${ }^{13} \mathrm{C}$ patterns, Table 4 demonstrates clear south-to-north depletion in ${ }^{13} \mathrm{C}$ beginning just above the Eocene/Oligocene boundary, but not below it. Although more synoptic data should be acquired, the data available at present corroborate a southern origin of the cooled mass of bottom waters after the Eocene/Oligocene boundary event.

If $N$. umbonifera can be used to trace cooled and corrosive bottom waters, one may wonder at its presence during Zone-P20 time at Site 526, with a paleodepth near 800 to $1000 \mathrm{~m}$. As discussed in the preceding section, faunal changes suggest that during that time a different intermediate-water mass appeared, impinging on the bottom at Site 526. Faunal and isotopic evidence both suggest a southern source of this intermediate-water mass. The presence of Indo-Pacific benthic forms implies a connection to that region. Indo-Pacific species had migrated into the Mediterranean (Braga et al., 1975) and into intermediate-depth sites of the equatorial Atlantic, the Bay of Biscay (Schnitker, 1979), and the Gulf of Mexico during the middle Eocene. Several different deep-water species are reported from the Paleogene of DSDP Site 360 in the Cape Basin (Proto Decima and Bolli, 1978). They did not occur at intermediate-depth eastern South Atlantic sites, however, before Zone-P20 time. The additional fact that similar species are not recorded from the southwestern Atlantic intermediatedepth sites on the Falkland Plateau or Rio Grande Rise (Tjalsma, 1977; 1983) further suggests the derivation of these forms from the direction of the Indian Ocean.

Isotopic evidence from the South Atlantic has demonstrated a stronger connection between the Indian Ocean and the middle-latitude southeastern Atlantic than between the southeastern and southwestern Atlantic. Evidence for this connection includes a strong east-west middle-latitude paleotemperature gradient, which resulted from the strong influence of equatorially derived nearsurface waters in the southwestern Atlantic (Boersma and Premoli Silva, 1983). Intermediate-depth bottom waters in the southeastern Atlantic were slightly cooler than in the southwestern Atlantic, though there was little overall temperature gradient through depth before the Eocene/Oligocene boundary event (Shackleton and Boersma, 1981). The paleotemperature data thus suggest cir-

Table 4. Carbon isotopic measurements $\left(\delta^{13} \mathrm{C}, \%_{0}\right)$ on Atlantic Eocene-Oligocene benthic foraminifers.

\begin{tabular}{|c|c|c|c|c|c|c|}
\hline $\begin{array}{l}V 27-202 \\
\text { Cape } \\
\text { Basin }\end{array}$ & $\begin{array}{c}529 \\
\text { Walvis } \\
\text { Ridge }\end{array}$ & $\begin{array}{c}357 \\
\text { Rio Grande } \\
\text { Rise }\end{array}$ & $\begin{array}{l}V 20-220 \\
\text { Brazil } \\
\text { Basin }\end{array}$ & $\begin{array}{l}94 \\
\text { Gulf of } \\
\text { Mexico }\end{array}$ & $\begin{array}{c}548 \\
\text { Bay of } \\
\text { Biscay }\end{array}$ & $\begin{array}{c}V 27-134 \\
\text { Bay of } \\
\text { Biscay }\end{array}$ \\
\hline 1.12 & 1.12 & 0.47 & $\begin{array}{c}0.60 \\
\text { Eocene }\end{array}$ & 1.13 & 1.27 & - \\
\hline 1.30 & 1.95 & - & $\begin{array}{c}\text { Oligocene } \\
1.73\end{array}$ & - & 0.74 & 0.45 \\
\hline
\end{tabular}

Note: Data are from Shackleton et al. (1984) and from N. J. Shackleton, A. Boersma, unpublished data. All values are based on measurements of Cibicidoides $\mathrm{sp}$. or are corrected to Cibicidoides according to the factors determined by Boersma and Shackleton (1977) and Shackleton et al. (1984). Samples are arranged from south to north. Eocene values are the uppermost Eocene measured at each site except Site 357, which is Zone P16 in age. Oligocene measurements are from the lowermost Oligocene at all sites. culation between the southeastern Atlantic and higher latitudes to the south and the southeast.

Unfortunately, isotopic data for Site 526 (Fig. 11) show no marked changes during Zone-P20 time correlative with the incursion of $N$. umbonifera into the 1000 -m paleodepth range. In view of the faunal changes already discussed, it is clear that a change at the bottom had occurred. It is possible, therefore, that isotopic measurements at this site contain a diagenetic overprint. Shackleton et al. (1984) also suggest a problem with intermediate depth measurements, on the basis of anomalous comparative benthic oxygen-isotopic values.

Kennett et al. (1975), Kennett (1980), and Jenkins (1979), among others, have proposed initiation of a fully circum-Antarctic surface circulation by late Oligocene time. The exact timing of this event remains uncertain, but possibly the pulse of $N$. umbonifera at shallow depths in the South Atlantic reflects the northern influence of the initiation of a "new," more corrosive intermediate water of southern origin, generated by the progressive opening of the Indian Ocean to the Pacific before the establishment of a fully circum-Atlantic surface circulation.

\section{The Evolution of Neogene Faunas and Water-Mass Structure}

The appearance of several typically Neogene benthic foraminiferal species in the late Oligocene in the Atlantic Ocean changed the general aspect of both deep-water and intermediate-water benthic foraminiferal assemblages, giving them a more "Neogene character" for the first time. These species include Uvigerina pygmaea, Rectuvigerina postprandia, Pullenia quinqueloba, Alabamina haitiensis, Trifarina bradyi, Eggerella bradyi, Heterolepa kullenber$g i$, and an as yet unidentified species of Textularia, called Textularia sp. A. The first occurrences of four of these species from north to south in the Atlantic are shown in Figure 12.

All these species are recorded first from the South Atlantic. Except for E. bradyi, T. bradyi, and $R$. postpran$d i a$, all first occurred in the deeper-water Sites 366, 529, and 357 in the South Atlantic and equatorial Atlantic during Zone-P21b time, synchronously with the extinction of Chiloguembelina spp. At South Atlantic intermediate-depth Site 526, the major change in species occurred first in Zone-P20 time with the appearances of a characteristic southwestern Pacific/early Oligocene cibicidid-anomalinid fauna (Boersma, 1984b) (which was more typical of the late Oligocene and early Neogene in the southeastern Atlantic), of Nuttallides umbonifera, of the rectuvigerinids, and of several shallower-water forms such as Nodogenerina sp. and Palmula sp. (Fig. 10). Later in Zone-P21 time, several other of the characteristically Neogene species already listed first occurred at Site 526 . Concurrently there was a sharp drop in specific diversity and in the overall abundance of benthic forms, paralleling an increase in sedimentation rate, which continued through the earliest Neogene at this site.

The appearances of these same taxa at deeper-water North Atlantic Sites 558, 563, and 549 were delayed until Zone-P21b-P22 time (Figs. 2-4), and accompanied 


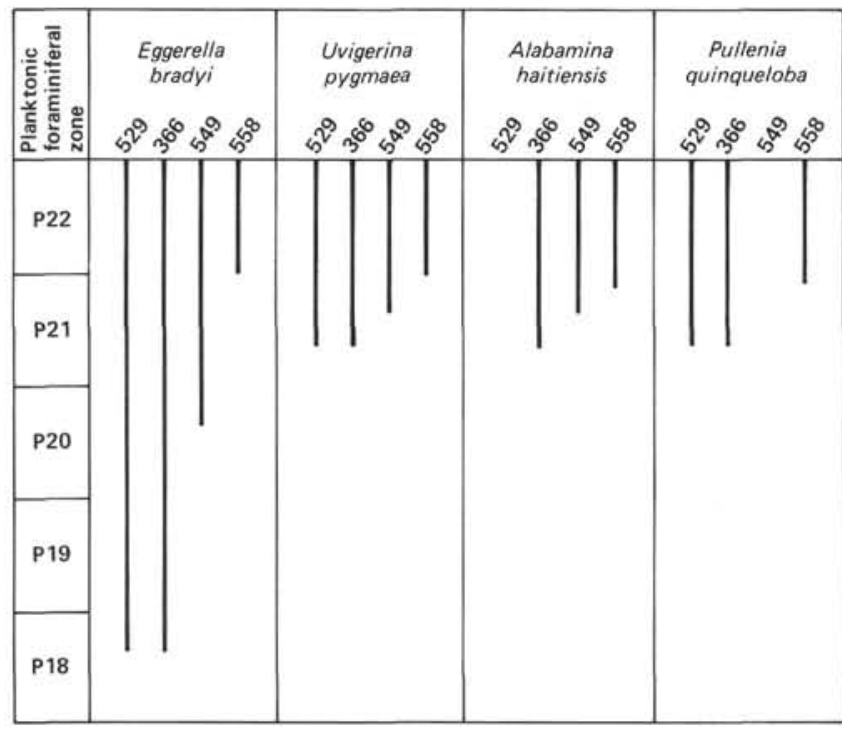

Figure 12. Stratigraphic distribution of four benthic species through the Oligocene at South Atlantic Site 529 on the Walvis Ridge, equatorial North Atlantic Site 366, Site 549 in the Bay of Biscay, and central North Atlantic Site 558. Data are summarized from Figures $2,4,5$, and 9 .

the retraction of $N$. umbonifera to deep ocean basins. Concurrently, a fauna containing Heterolepa mexicana first moved into the Bay of Biscay. Before this time, the $H$. mexicana fauna (called the Cibicidoides mexicanus fauna) is reported to have lived at bottom sites underlying the Norwegian Sea (Berggren and Schnitker, in press).

If benthic foraminiferal faunas reflect physicochemical water-mass properties as they affect the sediment/ water interface and hence the sediment in the Paleogene as they appear to do in the Quaternary, then it can be stated that a more typically Neogene water-mass stratification occurred diachronously through depth and between the North and South Atlantic. Deeper sites developed a Neogene character slightly later than shallower areas, and the North Atlantic later than the South Atlantic.

\section{CONCLUSIONS}

Comparison of Oligocene North Atlantic faunas from Sites 558, 563, 549, and 366 produced the following results:

1. At the two deepest sites, 558 and 563, with drilling depths near $3700 \mathrm{~m}$, individuals of most species are smaller than at the two shallower sites, 549 and 366 , both located in areas of moderate silica production. The percentages of rectilinear species are less at the deeper Sites 558 and 563 . Diversity, expressed as species richness, is also lower at the two deeper sites, which, in addition, often show the effects of significant carbonate dissolution.

2. Dissolution-resistant taxa include Globocassidulina subglobosa, Stilostomella abyssorum, Cibicidoides cf. ungerianus, and Pleurostomella alternans.

3. Criteria signaling decreased dissolution and possibly increased carbonate saturation levels include an increase in the rectilinear:rotaloid ratio and pulses of miliolids.
4. A "Barbados" fauna occurs at equatorial Site 366 and developed to a lesser degree at Site 549 in the Bay of Biscay. Diversity is highest at Site 366 , where intrageneric diversity is particularly high among the uvigerinids, cibicidids, anomalinids, nodosariids, and pleurostomellids. Robulinids are present, though not abundant, at Sites 549 and 366, but absent at the two deeper central Atlantic sites.

5. The New Zealand species Laticarinina altocamerata, Anomalinoides semiteres, and Rectuvigerina postprandia, and the Indo-Pacific genus Heronallenia all migrated into the Atlantic during Oligocene time.

6 . Sites 558 and 563 contain only large spino-costate uvigerinids in the lower Oligocene. A peak of uvigerinids accompanies a pulse of radiolarians in Zone P20 in the Bay of Biscay. Uvigerinids were diverse, only for a short period during Zone-P22 time at equatorial Site 366; $U$. pygmaea is the only common form of the genus in the upper Oligocene at all sites.

Comparison of coeval North and South Atlantic faunas to identify water-mass or biogeographic index species, and to determine their relation to the reorganization of oceanic circulation during the climatic shifts of the Oligocene, provides a basis for proposing the following summary interpretations:

1. The distribution of Nuttallides umbonifera parallels in general the oxygen-isotopic record of paleotemperatures. When bottom temperature dropped, $N$. umbonifera spread more widely through the North and South Atlantic and migrated upslope to depths near $2000 \mathrm{~m}$ in the South Atlantic and $2500 \mathrm{~m}$ in the North Atlantic. During the apparent warming of near-surface temperatures at the end of the Oligocene, $N$. umbonifera was restricted to deepest basinal areas. This species was generally more abundant, and occurred more consistently, in the South Atlantic.

2 . In the Oligocene the distribution of $N$. umbonifera from north to south and through the 2000-4000-m paleodepth range is an indicator of the pathway and distribution of "new" and/or cooled water-mass types, which aged from south to north thus demonstrating their southern origin.

3. The unusual occurrence and abundance of N. umbonifera near $900 \mathrm{~m}$ paleodepth on the Walvis Ridge at Site 526 during Zone-P20 time is interpreted to indicate the first influx of "new," surface-derived intermediate water, signaling the initiation of a circum-Antarctic circulation, which was fully developed in the late Oligocene. In this case the occurrence of $N$. umbonifera corresponds to the development of a "new" oxygenated, but not necessarily cooled, water type at the bottom.

4. The evolution of typically Neogene water-mass stratification in the North and South Atlantic is indicated by the appearances of typically Neogene benthic foraminiferal species through the latest Oligocene Zones P20P22. The appearances of these species suggest that the South Atlantic was restructured first by the introduction of a new intermediate-water in Zone-P20 time, which was followed by a new deep-water type later in ZoneP21b time. The North Atlantic, however, apparently acquired a more typically Neogene water-mass stratifica- 
tion in Zone-P22 time with the influx of deep waters possibly deriving from the Norwegian-Greenland Sea area.

\section{ACKNOWLEDGMENTS}

I would like to thank the scientists from DSDP Leg 82 for allowing me to study materials from their cruise. Thanks are also due to Dr. N. J. Shackleton for providing oxygen-isotopic and carbon-isotopic measurements on the foraminifers, and Drs. Leonard Tjalsma and Bill Sliter for critical review of the manuscript.

\section{REFERENCES}

Beckman, J. P., 1953. Die Foraminiferen der Oceanic Formation (Eocaen-Oligocaen) von Barbados, kl. Antillen. Eclogae Geol. Helv. 46:301-412.

Berggren, W. A., and Aubert, J., 1975. Paleocene benthic foraminiferal biostratigraphy, paleobiogeography, and paleoecology of the Atlantic-Tethyan regions: Midway-type fauna. Palaeogeogr., Palaeoclimatol., Palaeocol., 18:73-192.

Berggren, W. A., and Schnitker, D., 1983. Cenozoic marine environments in the North Atlantic and Norwegian-Greenland Sea. In Saxov, S. (Ed.), Structure and Development of the GreenlandScotland Ridge (NATO Adv. Res. Inst., Bressanne, Italy, 1981): New York (Plenum Press), pp. 495-548.

Bettenstaedt, R. L., and Wicher, L., 1955. Stratigraphic correlation of Upper Cretaceous and Lower Cretaceous in the Tethys and Boreal by the aid of microfossils. Proc. 4th World Pet. Congr., Sec. I/D, pap. 5:494-516.

Boersma, A., 1977. Eocene-Oligocene benthic Foraminifera-DSDP Leg 39 (South Atlantic). In Supko, P. R., Perch-Nielsen, K., et al., Init. Repts. DSDP, 39: Washington (U.S. Govt. Printing Office), 567-591.

1984a. Cretaceous-Tertiary planktonic foraminifers from the southeastern Atlantic, Walvis Ridge Area, Deep Sea Drilling Project, Leg 74. In Moore, T. C., Jr., Rabinowitz, P. D., et al., Init. Repts. DSDP, 74: Washington (U.S. Govt. Printing Office), 501-524.

1984b. Pliocene planktonic and benthic foraminifers from the southeastern Atlantic Angola Margin: Leg 75, Site 532, Deep Sea Drilling Project. In Hay, W. W., Sibuet, J.-C., et al., Init. Repts. DSDP, 75: Washington (U.S. Govt. Printing Office), 657-670.

Boersma, A., and Premoli Silva, I., 1983. Paleocene planktonic foraminiferal biogeography and the paleooceanography of the Atlantic Ocean. Micropaleontology, 29:355-381.

Boersma, A., Shackleton, N. J., 1977. Tertiary oxygen and carbon isotopic stratigraphy: Site 357 (mid-latitude South Atlantic). In Supko, P. R., Perch-Nielsen, K., et al., Init. Repts. DSDP, 39: Washington (U.S. Govt. Printing Office), 911-924.

1978. Oxygen and carbon isotope record through the Oligocene, DSDP Site 366, equatorial Atlantic. In Lancelot, Y., Siebold, E., et al., Init. Repts. DSDP, 41: Washington (U.S. Govt. Printing Office), 957-962.

Bonatti, E., Sarntheim, M., Boersma, A., Gorini, M., and Honnorez, J., 1977. Crustal emersion and subsidence in the Romanche Fracture Zone, equatorial Atlantic. Earth Planet. Sci. Lett., 35:369-383.

Braga, G., de Biase, R., Grunig, A., and Proto Decima, F., 1975. Foraminiferi bentonici del Paleocene ed Eocene della sezione di Possagno. Schweiz. Palaontol., 97:85-111.

Bremer, M., and Lohman, G., 1982. Evidence for primary control of the distribution of certain Atlantic Ocean benthonic Foraminifera by degree of carbonate saturation. Deep-Sea Res., 29:987-998.

Broecker, W., 1974. Chemical Oceanography: New York (Harcourt Brace Jovanovich).

Brouwer, J., 1965. Agglutinated foraminiferal faunas from some turbidite sequences. I. Koninkl. Ned. Akad. Wetenschap. Proc., 68 309-334.

Corliss, J., 1981. Deep-Sea benthonic foraminiferal faunal turnover near the Eocene/Oligocene boundary. Mar. Micropaleontol., 6 : 367-384.

Dean, W., Gardner, J., Jansa, L. F., Cêpek, P., and Seibold, E., 1978. Cyclic sedimentation along the continental margin of northwest Africa. In Lancelot, Y., Seibold, E., et al., Init. Repts. DSDP, 41: Washington (U.S. Govt. Printing Office), 965-991.
Finlay, H. J., 1939. New Zealand Foraminifera. Key species in stratigraphy, no. 3. Trans. Proc. Roy. Soc. N. Z., 69:309-329.

Gradstein, F., and Berggren, W. A., 1981. Flysch-type agglutinated Foraminifera and the Maestrichtian to Paleogene history of the Labrador and north seas. Mar. Micropaleontol. 6:211-268.

Hardenbol, J., and Berggren, W. A., 1978. A new Paleogene numerical time scale. Am. Assoc. Pet. Geol., Studies in Geology, 6: 213-234.

Jenkins, D. G., 1979. Guembelitria aff. stavensis Bandy, a paleooceanographic marker of the initiation of the circum-Antarctic current and the opening of the Drake Passage. In Bolli, H. M., Ryan, W. B. F., et al., Init. Repts. DSDP, Suppl. to Vols. 38, 39, 40, and 41, Pt. III: Washington (U.S. Govt. Printing Office), 687-695.

Keigwin, L., 1980. Paleooceanographic change in the Pacific at the Eocene/Oligocene boundary. Nature, 287:722-725.

Kennett, J. P., 1980. Paleooceanographic and biogeographic evolution of the Southern Ocean during the Cenozoic, and Cenozoic microfossil datums. Palaeogeogr., Palaeoclimatol., Palaeoecol., 31: 123-152.

Kennett, J. P., and Shipboard Scientific Party, 1975. Antarctic glaciation and the development of the circum-Antarctic current. In Kennett, J. P., Houtz, R. E., et al., Init. Repts. DSDP, 29: Washington (U.S. Govt. Printing Office), 1155-1170.

Kroopnick, P., 1974. Correlation between ${ }^{13} \mathrm{C}$ and $\mathrm{CO}_{2}$ in surface waters and atmospheric $\mathrm{CO}_{2}$. Earth Planet. Sci. Lett., 22:397-403.

Lutze, G. F., 1978. Neogene benthonic Foraminifera from Site 369, Leg 41, Deep Sea Drilling Project. In Lancelot, Y., Seibold, E., et al., Init. Repts. DSDP, 41: Washington (U.S. Govt. Printing Office), 659-666.

McCoy, F., and Zimmerman, H., 1977. A history of sediment lithofacies in the South Atlantic Ocean. In Supko, P. R., Perch-Nielsen, K., et al., Init. Repts. DSDP, 39: Washington (U.S. Govt. Printing Office), 1047-1079.

Mathews, R., and Poore, R., 1980. Tertiary ${ }^{18} \mathrm{O}$ record and glacio-eustatic sea level fluctuations. Geology, 8:501-504.

Melguen, M., 1978. Facies evolution, carbonate sediments from eastern South Atlantic (DSDP Leg 40) since the early Cretaceous. In Bolli, H. M., Ryan, W. B. F., et al., Init. Repts. DSDP, 40: Washington (U.S. Govt. Printing Office), 981-1025.

Miller, K., 1982. Late Paleogene (Eocene to Oligocene) paleooceanography of the northern North Atlantic [unpublished Ph.D dissertation]. Woods Hole Oceanographic Inst.

Moore, T. C., Jr., Rabinowitz, P. D., et al., 1984. Init. Repts. DSDP, 74: Washington (U.S. Govt. Printing Office).

Ness, G., Levi, S., and Couch, R., 1980. Marine magnetic anomaly timescales for the Cenozoic and Cretaecous. Rev. Geophys. Space Phys., 18:753-770.

Nuttall, W. L. F., 1932. Lower Oligocene Foraminifera from Mexico. J. Paleontol., 6(1):3-35.

Proto Decima, F., and Bolli, H., 1978. Southeastern Atlantic Leg 40 Paleogene benthic Foraminifera. In Bolli, H. M., Ryan, W. B. F., et al., Init. Repts. DSDP, 40: Washington (U.S. Govt. Printing Office), 783-809.

Rey, M., 1954. Comparison des microfaunes du Nummulitique Nord Marocain et du Golfe du Mexique et de la Mer des Caraïbes. Int. Geol. Congr. Alger., pp. 39-60.

Savin, S., 1977. The history of the earth's surface temperature during the past 100 million years. Annu. Rev. Earth Planet. Sci., 5: 319-355.

Schnitker, D., 1974. Western Atlantic abyssal circulation during the past 120,000 years. Nature, 248:385-387.

1979. Cenozoic deep water benthic Foraminifera, Bay of Biscay. In Montadert, L., Roberts, D. G., et al., Init. Repts. DSDP, 48: Washington (U.S. Govt. Printing Office), 377-413.

Shackleton, N. J., and Boersma, A., 1981. The climate of the Eocene ocean. J. Geol. Soc., London, 138:153-157.

Shackleton, N. J., Hall, M. A., and Boersma, A., 1984. Oxygen and carbon isotope data from Leg 74 foraminifers. In Moore, T. C., Jr., Rabinowitz, P. D., et al., Init. Repts. DSDP, 74: Washington (U.S. Govt. Printing Office), 599-612.

Shackleton, N. J., and Kennett, J. P., 1975. Paleotemperature history of the Cenozoic and the initiation of Antarctic glaciation: oxygen and carbon isotope analyses in DSDP Sites 277, 279 and 284. In Kennett, J. P., Houtz, R. E., et al., Init. Repts. DSDP, 29: Washington (U.S. Govt. Printing Office), 743-755. 
Streeter, S., 1973. Bottom water and benthic Foraminifera in the North Atlantic: Glacial:interglacial contrasts. Quat. Res., 3: 131-141.

Supko, P. R., Perch-Nielsen, K., et al., 1977. Init. Repts. DSDP, 39: Washington (U.S. Govt. Printing Office).

Tjalsma, R. C., 1977. Cenozoic Foraminifera from the South Atlantic, DSDP Leg 36. In Barker, P., Dalziel, I. W. D., et al., Init. Repts. DSDP, 36: Washington (U.S. Govt. Printing Office), 493-517.

1983. Eocene to Miocene benthic foraminifers from DSDP Site 516, Rio Grande Rise, South Atlantic. In Barker, P. F., Carlson, R. L., Johnson, D. A., et al., Init. Repts. DSDP, 72: Washington (U.S. Govt. Printing Office), 731-755.

Tjalsma, R. C., and Lohmann, G. P., 1983. Paleocene-Eocene bathyal and abyssal benthic Foraminifera from the Atlantic Ocean. Micropaleontology Spec. Publ. 4.
Tucholke, B., and Vogt, P., 1979. Western North Atlantic: sedimentary evolution and aspects of tectonic history. In Tucholke, B. E., Vogt, P. R., et al., Init. Repts. DSDP, 43: Washington (U.S. Govt. Printing Office), 791-826.

Vernaud Grazzini, C., Müller, C., Létolle, C. P., Peypouquet, J., 1979. Stable isotopes and Tertiary paleontological paleooceanography in the northeast Atlantic. In Montadert, L., Roberts, D. G., et al., Init. Repts. DSDP, 48: Washington (U.S. Govt. Printing Office), 475-491.

Woodruff, F., 1979. Deep sea benthic foraminiferal changes associated with the middle Miocene oxygen isotopic event, DSDP Site 289, equatorial Pacific [unpublished Ph.D. thesis]. Univ. of Southern California, Los Angeles, California.

Date of Initial Receipt: 1 August 1983

Date of Acceptance: 2 March 1984 